\title{
Ozone production efficiency in an urban area
}

\author{
Lawrence I. Kleinman, Peter H. Daum, Yin-Nan Lee, Linda J. Nunnermacker, \\ and Stephen R. Springston \\ Atmospheric Sciences Division, Brookhaven National Laboratory, Upton, New York, USA \\ Judith Weinstein-Lloyd \\ Chemistry/Physics Department, State University of New York at Old Westbury, Old Westbury, New York, USA \\ Jochen Rudolph \\ Chemistry Department and Centre for Atmospheric Research, York University, Toronto, Ontario, Canada
}

Received 13 May 2002; revised 1 August 2002; accepted 1 August 2002; published 14 December 2002.

[1] Ozone production efficiency can be defined as the number of molecules of oxidant $\left(\mathrm{O}_{3}+\mathrm{NO}_{2}\right)$ produced photochemically when a molecule of $\mathrm{NO}_{\mathrm{x}}\left(\mathrm{NO}+\mathrm{NO}_{2}\right)$ is oxidized. It conveys information about the conditions under which $\mathrm{O}_{3}$ is formed and is an important parameter to consider when evaluating impacts from $\mathrm{NO}_{\mathrm{x}}$ emission sources. We present calculational and observational results on ozone production efficiency based on measurements made from aircraft flights in the Phoenix metropolitan area in May and June of 1998. Constrained steady state box model calculations are used to relate a ratio of $\mathrm{O}_{3}$ production rate to $\mathrm{NO}_{\mathrm{x}}$ consumption rate (i.e., $\mathrm{P}\left(\mathrm{O}_{3}\right) / \mathrm{P}\left(\mathrm{NO}_{\mathrm{z}}\right)$ ) to a $\mathrm{VOC}$ to $\mathrm{NO}_{2}$ ratio of $\mathrm{OH}$ reactivity. Lagrangian calculations show how this ratio generally increases with time due to oxidation chemistry and plume dilution. City to city differences in ozone production efficiency can be attributed to corresponding differences in VOC to $\mathrm{NO}_{2}$ reactivity ratio which in turn reflect emission patterns. Ozone production efficiencies derived from aircraft measurements in 20 plumes show a dependence on $\mathrm{NO}_{\mathrm{x}}$ concentration similar to that calculated for $\mathrm{P}\left(\mathrm{O}_{3}\right) / \mathrm{P}\left(\mathrm{NO}_{\mathrm{z}}\right)$. Calculations are based on data from a single location but are believed to be applicable to a wide range of plumes from different areas. INDEX TERMS: 0322 Atmospheric Composition and Structure: Constituent sources and sinks; 0345 Atmospheric Composition and Structure: Pollution—urban and regional (0305); 0365 Atmospheric Composition and Structure: Troposphere - composition and chemistry; KEYWORDS: ozone production efficiency, urban plume, urban photochemistry, photochemistry, Phoenix

Citation: Kleinman, L. I., P. H. Daum, Y.-N. Lee, L. J. Nunnermacker, S. R. Springston, J. Weinstein-Lloyd, and J. Rudolph, Ozone production efficiency in an urban area, J. Geophys. Res., 107(D23), 4733, doi:10.1029/2002JD002529, 2002.

\section{Introduction}

[2] Ozone is formed in the lower troposphere from a series of photochemical reactions requiring volatile organic compounds (VOCs), $\mathrm{NO}_{\mathrm{x}}\left(\mathrm{NO}+\mathrm{NO}_{2}\right)$, and sunlight. Control of $\mathrm{O}_{3}$ is accomplished by reducing emissions of $\mathrm{NO}_{\mathrm{x}}$ and/or VOCs so it is of great practical importance to know how each factor contributes to $\mathrm{O}_{3}$ production. In the $\mathrm{O}_{3}$ forming sequence of reactions, $\mathrm{NO}_{\mathrm{x}}$ is a catalyst that can produce several molecules of $\mathrm{O}_{3}$ before it is removed from the atmosphere by oxidation reactions. Liu et al. [1987] and Lin et al. [1988] were the first to use a photochemical model to specifically examine the number of $\mathrm{O}_{3}$ molecules produced from a molecule of $\mathrm{NO}_{\mathrm{x}}$. They called this quantity an ozone production efficiency, which we will denote as OPE. These authors found that the nonlinearity of the photochemical equations caused OPE to depend on $\mathrm{NO}_{\mathrm{x}}$ concen-

Copyright 2002 by the American Geophysical Union. 0148-0227/02/2002JD002529\$09.00 tration. $\mathrm{A} \mathrm{NO}_{\mathrm{x}}$ molecule could be an order of magnitude more effective in forming $\mathrm{O}_{3}$ in clean remote regions (high OPE) as compared with a polluted region (low OPE).

[3] Although the basic features of photochemical $\mathrm{O}_{3}$ formation are well understood from laboratory and modeling studies, field observations are needed to confirm this understanding and to determine how a complicated nonlinear system evolves under the actual driving forces of emissions and meteorology. Trainer et al. [1993] showed how an ozone production efficiency could be deduced from atmospheric observations. They determined OPE as the slope of a graph of $\mathrm{O}_{3}$ concentration versus the concentration of $\mathrm{NO}_{\mathrm{x}}$ oxidation products. The latter quantity is denoted as $\mathrm{NO}_{z}$ and is commonly measured as the difference between $\mathrm{NO}_{\mathrm{y}}$ (sum of all odd-nitrogen compounds) and $\mathrm{NO}_{\mathrm{x}}$, (i.e. $\mathrm{NO}_{\mathrm{z}}=\mathrm{NO}_{\mathrm{y}}-\mathrm{NO}_{\mathrm{x}}$ ). Although originally OPE was defined in terms of $\mathrm{O}_{3}$ and $\mathrm{NO}_{\mathrm{z}}$, a slightly different definition will be used here, replacing $\mathrm{O}_{3}$ by $\mathrm{O}_{x}$ (odd oxygen $=\mathrm{O}_{3}+\mathrm{NO}_{2}$ ). This substitution is made because $\mathrm{O}_{\mathrm{x}}$ tends to be more of a conserved quantity than $\mathrm{O}_{3}$ in that 
it is not affected by the titration reaction, $\mathrm{NO}+\mathrm{O}_{3} \rightarrow \mathrm{NO}_{2}$, when $\mathrm{NO}_{\mathrm{x}}$ is added to an air mass. The definition of OPE as the slope of a plot of $\mathrm{O}_{3}$ ( or $\mathrm{O}_{\mathrm{x}}$ ) versus $\mathrm{NO}_{\mathrm{z}}$ is only one of several possibilities. As described by Sillman [2000], the numerical value of OPE and even its interpretation depends on which definition is used. The determination of an OPE that reflects only chemical production of $\mathrm{O}_{3}$ can be problematic because of other factors such as dry deposition that affects both $\mathrm{O}_{3}$ and $\mathrm{NO}_{\mathrm{z}}$ [Trainer et al., 1993].

[4] OPE has been determined in several field studies, qualitatively confirming its predicted inverse dependence on $\mathrm{NO}_{\mathrm{x}}$ concentration. In low $\mathrm{NO}_{\mathrm{x}}$ rural areas OPE was found to have a high value of about 10 [Trainer et al., 1993; Olszyna et al., 1994; Kleinman et al., 1994]. Observations in urban plumes indicate values of OPE between 2 and 4 in NYC [Kleinman et al., 2000] and between 3 and 6 in Nashville [St. John et al., 1998; Nunnermacker et al., 1998; R.A. Zaveri et al., Ozone production efficiency and $\mathrm{NO}_{\mathrm{x}}$ depletion in an urban plume, submitted to Journal of Geophysical Research, 2002]. A comparison of plumes from power plants located near Nashville shows the effects of $\mathrm{NO}_{\mathrm{x}}$ concentration on OPE. The large Cumberland (124 $\mathrm{k}$ ton $\mathrm{NO}_{\mathrm{x}} \mathrm{yr}^{-1}$ (metric tons, as $\left.\mathrm{NO}_{2}\right)$ ) and Paradise $(120 \mathrm{k}$ ton $\mathrm{NO}_{\mathrm{x}} \mathrm{yr}^{-1}$ ) plumes have an OPE of 1-3, while the smaller Gallatin (11 kton $\left.\mathrm{NO}_{\mathrm{x}} \mathrm{yr}^{-1}\right)$ and Johnsonville (17 kton $\mathrm{NO}_{\mathrm{x}} \mathrm{yr}^{-1}$ ) plumes have an OPE of about 3-7 [Gillani et al., 1998; Nunnermacker et al., 2000; Ryerson et al., 2001]. Effects of VOC reactivity are found in a comparison between power plants. Those located in a region with high isoprene emissions have a significantly higher OPE than an equivalent sized plant in a low isoprene emitting region [Luria et al., 2000; Ryerson et al., 2001]. Implications of OPE on siting strategies for power plants are discussed by Ryerson et al. [2001]. Chemical-transport model calculations and monitoring data have been used to simulate OPE in individual plumes [Sillman, 2000] and to predict regional scale consequences [Jacob et al., 1993; Kasibhatla et al., 1998]. The ratio of $\mathrm{O}_{3}$ to $\mathrm{NO}_{\mathrm{z}}$ has been used by Sillman [1995] as an indicator of whether $\mathrm{O}_{3}$ was formed under $\mathrm{NO}_{\mathrm{x}}$ limited (high ratio) or VOC limited (low ratio) conditions.

[5] In this article we examine the dependence of OPE on $\mathrm{O}_{3}$ precursors. We are motivated by the possibility that relatively easy to obtain values of OPE can provide information on the concentration of $\mathrm{O}_{3}$ precursors. Differences in OPE from one plume to another and from one city to another could then be interpreted in terms of differences in precursor concentrations and ultimately in terms of precursor emission rates. It is important to have observation-based methods of obtaining information on $\mathrm{O}_{3}$ precursors that are independent of model predictions which depend on uncertain emission estimates. We present results based on trace gas measurements obtained from the DOE G1 aircraft during a field campaign conducted in Phoenix, AZ during the late spring of 1998. Although our examples are all taken from a single field campaign we believe that results presented in this study are applicable to a wide range of urban and power plant plumes.

[6] OPE and related quantities are examined from three perspectives. First, we consider the instantaneous chemistry in an air parcel using a constrained steady state (CSS) box model to calculate the rate of $\mathrm{O}_{3}$ production, $\mathrm{P}\left(\mathrm{O}_{3}\right)$, and the rate of $\mathrm{NO}_{\mathrm{x}}$ consumption, $\mathrm{P}\left(\mathrm{NO}_{\mathrm{z}}\right)$. The ratio of these quantities, $\mathrm{P}\left(\mathrm{O}_{3}\right) / \mathrm{P}\left(\mathrm{NO}_{z}\right)$, is the number of $\mathrm{O}_{3}$ molecules chemically produced per $\mathrm{NO}_{\mathrm{x}}$ molecule consumed at the time and place where the observations are made. We derive and evaluate analytic formulas that give $\mathrm{P}\left(\mathrm{O}_{3}\right) / \mathrm{P}\left(\mathrm{NO}_{\mathrm{z}}\right)$ in terms of observed concentrations of $\mathrm{NO}_{2}$ and VOCs; specifically a VOC to $\mathrm{NO}_{2}-\mathrm{OH}$ reactivity ratio. This work builds upon and extends previous research by Derwent and Davies [1994], Daum et al. [2000] and Carpenter et al. [2000]. Second, we use the Lagrangian perspective where an observer follows an air parcel as it is advected away from a source region, undergoing chemical reactions and dilution with background air. From time dependent Lagrangian calculations we determine the systematic changes in VOCs and $\mathrm{NO}_{2}$ and the concomitant changes in $\mathrm{P}\left(\mathrm{O}_{3}\right)$ / $\mathrm{P}\left(\mathrm{NO}_{\mathrm{z}}\right)$ that occur as an air mass ages. The dependence of OPE on instantaneous rates in an evolving air mass is discussed, leading to a scaling relation that attributes place to place differences in OPE to differences in the ambient VOC to $\mathrm{NO}_{2}-\mathrm{OH}$ reactivity ratio. Third, is the Eulerian perspective, in which an observer traverses a plume and uses $\mathrm{O}_{3}, \mathrm{NO}_{\mathrm{x}}$, and $\mathrm{NO}_{\mathrm{y}}$ measurements to deduce OPE. Properties of OPE determined in this way are illustrated using aircraft observations made in transects of the Phoenix urban plume.

\section{Phoenix Field Campaign}

[7] In May and June of 1998, researchers at the Arizona Department of Environmental Air Quality, Argonne National Laboratory, Brookhaven National Laboratory, and Pacific Northwest National Laboratory conducted a photochemistry field campaign in the Phoenix metropolitan area [Fast et al., 2000]. Observations were made from surface sites and from the DOE G-1 aircraft. Sampling from the G-1 was done in background air, over the city in high emission rate regions, and downwind of the city where $\mathrm{O}_{3}$ production was expected.

[8] Measurements included $\mathrm{O}_{3}, \mathrm{NO}, \mathrm{NO}_{2}, \mathrm{NO}_{\mathrm{y}}$, speciated VOCs, $\mathrm{CO}, \mathrm{H}_{2} \mathrm{O}_{2}$, organic peroxides, $\mathrm{HCHO}$, temperature, pressure, water vapor, and UV irradiance. Instrumentation was similar to that deployed in other field programs (see Lee et al. [1998] for HCHO; Weinstein-Lloyd et al. [1998] for peroxides; Rudolph [1999] for VOCs and Nunnermacker et al. [1998] for the remaining trace gases). Of particular importance for the present study are the observations of $\mathrm{O}_{3}$, odd $\mathrm{N}$ compounds, and VOCs. Ozone was measured using a commercial UV absorption instrument. Oxides of nitrogen were measured using a three-channel $\mathrm{NO} / \mathrm{O}_{3}$ chemiluminescence instrument. $\mathrm{NO}_{2}$ is converted to $\mathrm{NO}$ by photolysis; $\mathrm{NO}_{\mathrm{y}}$ is converted to $\mathrm{NO}$ using a heated $\left(350^{\circ} \mathrm{C}\right)$ Mo catalyst. VOCs were collected in $3-\mathrm{L}$ SUMMA $^{\circledR}$ electropolished stainless steel canisters and analyzed at York University by GC-FID [Rudolph, 1999].

[9] The Phoenix metropolitan area has a population of 3 million people located in a basin defined by mountains on three sides. Emissions are primarily due to area and mobile sources [Heisler et al., 1997]. Vegetation is sparse and biogenic VOC emissions are low. In the late spring the climate is hot, dry, and largely cloud free. PAN concentrations measured at the surface were low, typically below $1 \mathrm{ppb}$, consistent with the high ambient temperature [Gaffney et al., 2000]. Although solar insolation is high, the ozone 
Table 1. Notation

\begin{tabular}{clc}
\hline \multicolumn{1}{c}{ Frame } & \multicolumn{1}{c}{ Symbol } & Meaning \\
\hline Instantaneous & $\mathrm{P}$ & chemical production rate \\
& $\mathrm{L}$ & chemical loss rate \\
& $\mathrm{P}\left(\mathrm{O}_{3}\right) / \mathrm{P}\left(\mathrm{NO}_{\mathrm{z}}\right)$ & $\begin{array}{c}\text { instantaneous } \mathrm{O}_{3} \\
\text { production efficiency }\end{array}$ \\
& $\left(\mathrm{P}\left(\mathrm{O}_{3}\right)-\mathrm{L}\left(\mathrm{O}_{3}\right)\right) / \mathrm{P}\left(\mathrm{NO}_{\mathrm{z}}\right)$ & $\begin{array}{c}\text { instantaneous net } \mathrm{O}_{3} \\
\text { production efficiency }\end{array}$ \\
& & $\begin{array}{c}\text { concentration change } \\
\text { Integrated }\end{array}$ \\
& $\Delta$ & $\begin{array}{c}\Delta \mathrm{O}_{\mathrm{x}} / \Delta \mathrm{NO}_{\mathrm{z}} \text { : ozone } \\
\text { production efficiency }\end{array}$ \\
& $\mathrm{OPE}$ &
\end{tabular}

production rate is calculated to be significantly lower than in other cities due to the low rate of radical production from photolysis of $\mathrm{O}_{3}$ followed by reaction of $\mathrm{O}^{1} \mathrm{D}$ with $\mathrm{H}_{2} \mathrm{O}$. Ozone production efficiency, in contrast, as shown below, does not directly depend on radical production rate, so Phoenix will not be atypical because of its dry atmosphere.

\section{Notation}

[10] Notation used in this article is summarized in Table 1. Two time frames are defined: instantaneous and integrated (called "present" and "past" by Kleinman, [2000]). Instantaneous refers to quantities that can be calculated from a knowledge of chemical concentrations at a single point in time and space. Examples are rates and ratios of rates, i.e., $\mathrm{P}\left(\mathrm{O}_{3}\right)$ and $\mathrm{P}\left(\mathrm{O}_{3}\right) / \mathrm{P}\left(\mathrm{NO}_{z}\right)$. Integrated quantities are ones that depend on the time evolution of an air mass. Examples are concentrations and concentration changes. There are multiple ways of defining concentration changes. In the Lagrangian frame a change is defined relative to conditions in the same air mass at an earlier time, for example upwind of an emission source. An Eulerian definition compares concentrations at different positions, for example in the center of a plume and in background air outside of the plume.

\section{Photochemical Models}

\subsection{Constrained Steady State}

[11] A photochemical box model was used to calculate the concentrations of rapidly reacting species (i.e., $\mathrm{OH}$, $\mathrm{HO}_{2}, \mathrm{RO}_{2}$, and $\mathrm{NO}_{2}$ ) that are in steady state with an observed mixture of stable trace gases. Inputs to this model are observed or estimated values for $\mathrm{O}_{3}, \mathrm{NO}, \mathrm{CO}$, VOCs, $\mathrm{HCHO}, \mathrm{H}_{2} \mathrm{O}_{2}$, organic peroxides, $\mathrm{H}_{2} \mathrm{O}$, solar intensity, temperature, and pressure. The limiting factor in assembling the input data for the CSS calculations is, in general, the availability of VOC observations, which are obtained from discrete canister samples. A typical sampling time is $30 \mathrm{~s}$. Concentrations from the faster responding trace gas and meteorological instruments were averaged over this collection time. An additional minute of averaging was allowed in those cases where an instrument was being calibrated or zeroed. Calculations were performed for all VOC samples as long as there were measurements for $\mathrm{O}_{3}, \mathrm{NO}, \mathrm{CO}$, and state parameters. In about $25 \%$ of the cases there were missing values for one or more of the other trace gases. Missing data was replaced by estimated values: $\mathrm{HCHO}$ was set to a calculated steady state value in which production and loss rates are equal; peroxides were qualitatively estimated based on their correlation with $\mathrm{O}_{3}$ and dew point.

[12] The model consists of a set of differential equations that represent kinetic rate expressions from the chemical mechanism of Stockwell et al. [1990] and the condensed isoprene oxidation mechanism of Paulson and Seinfeld [1992]. Of particular importance for the current application is the rate constant for $\mathrm{OH}+\mathrm{NO}_{2}$, which was recently revised downward [Atkinson et al., 1997]. PAN type compounds are not included in the CSS calculations; these compounds are assumed to be in steady state. Photolysis rate constants were calculated using short wave UV irradiance measurements from an Eppley radiometer and programs from Madronich [1987]. In the CSS calculations the concentrations of stable species are fixed at their observed (or estimated) values. $\mathrm{CH}_{4}$ is fixed at $1750 \mathrm{ppb}$. A model run consists of a 5- or 10-min integration, during which time free radicals and $\mathrm{NO}_{2}$ come into equilibrium. Further information on the photochemical calculations are given by Kleinman et al. [1997].

[13] In addition to concentrations of radicals and $\mathrm{NO}_{2}$, the CSS calculations provide rates of individual reactions or groups of reactions. For this study we will make use of the production and loss rate of $\mathrm{O}_{3}, \mathrm{P}\left(\mathrm{O}_{3}\right)$ and $\mathrm{L}\left(\mathrm{O}_{3}\right)$, and the production rate of $\mathrm{NO}_{\mathrm{x}}$ oxidation products, $\mathrm{P}\left(\mathrm{NO}_{\mathrm{z}}\right)$. The net number of $\mathrm{O}_{3}$ molecules formed for each molecule of $\mathrm{NO}_{x}$

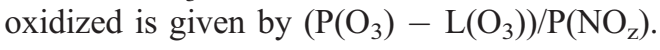

\subsection{Lagrangian Model}

[14] With some minor modifications the CSS model becomes a Lagrangian model used to follow the time evolution of an air parcel starting from a specified initial state. In the Lagrangian calculations the only species that are constrained are $\mathrm{CH}_{4}$ and $\mathrm{H}_{2} \mathrm{O}$; PAN and analogs are calculated variables. The Lagrangian model has provisions for dilution of the air parcel with background air having a specified composition. In this study calculations are initialized with a set of chemical concentrations based on observations at 1000 local time (LT). Chemical rate equations are integrated to 1700 LT using diurnally varying photolysis rate constants as appropriate for Phoenix on June 1.

\section{Photochemical Model Results}

[15] In order to understand the time and transport dependent process leading to $\mathrm{O}_{\mathrm{x}}$ and $\mathrm{NO}_{\mathrm{z}}$ formation in an air mass it is useful to first consider the chemistry occurring in an air mass as a sequence of snapshots. At each point in time we can use a photochemical box model to determine the rates at which $\mathrm{O}_{3}$ and $\mathrm{NO}_{z}$ are being formed. In this section we show how $\mathrm{P}\left(\mathrm{O}_{3}\right) / \mathrm{P}\left(\mathrm{NO}_{\mathrm{z}}\right)$ is related to the concentration of $\mathrm{O}_{3}$ precursors.

\subsection{Steady State Formulas for $\mathbf{P}\left(\mathrm{O}_{3}\right) / \mathbf{P}\left(\mathrm{NO}_{\mathbf{z}}\right)$}

[16] Derwent and Davies [1994], Daum et al. [2000], and Carpenter et al. [2000] have derived steady state formulas for $\mathrm{P}\left(\mathrm{O}_{3}\right) / \mathrm{P}\left(\mathrm{NO}_{\mathrm{z}}\right)$. These formulas differ in detail but all express $\mathrm{P}\left(\mathrm{O}_{3}\right) / \mathrm{P}\left(\mathrm{NO}_{\mathrm{z}}\right)$ in terms of the $\mathrm{OH}$ reactivity ratio of VOCs to $\mathrm{NO}_{2}$. The derivation given below builds on wellcharacterized photochemical reactions [see, e.g., Seinfeld and Pandis, 1997; Finlayson-Pitts and Pitts, 2000] and 
follows that of Daum et al. [2000], with additional attention given to side reactions and to the domain of validity.

[17] Ozone is formed as part of a chain reaction with the following steps:

$$
\begin{gathered}
\mathrm{HO}_{2}+\mathrm{NO} \rightarrow \mathrm{OH}+\mathrm{NO}_{2} \\
\mathrm{RO}_{2}+\mathrm{NO} \rightarrow \text { carbonyl }+\mathrm{HO}_{2}+\mathrm{NO}_{2} \\
\mathrm{RO}_{2}^{\prime}+\mathrm{NO} \rightarrow \text { carbonyl }+\mathrm{RO}_{2}+\mathrm{NO}_{2} \\
\mathrm{NO}_{2}+\mathrm{h} \nu \rightarrow \mathrm{NO}+\mathrm{O}_{3}
\end{gathered}
$$

As used in reaction ( $\mathrm{R} 1)$, the term "VOC" is defined very broadly to include all substances (e.g., $\mathrm{CO}, \mathrm{SO}_{2}, \mathrm{O}_{3}$, $\mathrm{HCHO}$, hydrocarbons) that react with $\mathrm{OH}$ producing peroxy radicals. Reaction (1) is written to allow for the possibility that there are multiple channels producing a combination of $\mathrm{HO}_{2}$ and $\mathrm{RO}_{2}$. Two types of organic peroxy radicals are identified according to the chemistry of the RO radical which is formed as the immediate product of reaction (R3a) or (R3b) [e.g., Atkinson, 2000]. Examples of $\mathrm{RO}_{2}$ and $\mathrm{RO}_{2}^{\prime}$ are the methylperoxy, $\mathrm{CH}_{3} \mathrm{O}_{2}$, and the acetylperoxy, $\mathrm{CH}_{3} \mathrm{C}(\mathrm{O}) \mathrm{O}_{2}$, radical, respectively. The peroxy radical yield (i.e., $\alpha+\beta+\gamma$ ) is usually close to 1 but can be somewhat lower because of organic nitrate formation. Assuming that reaction (R1) is rate limiting and that reactions (R1) to (R4) provide a complete description of $\mathrm{O}_{3}$ formation, we obtain

$$
\mathrm{P}\left(\mathrm{O}_{3}\right)=\Sigma \mathrm{Y}_{\mathrm{i}} \mathrm{k}_{\mathrm{i}}\left[\mathrm{VOC}_{\mathrm{i}}\right][\mathrm{OH}]
$$

where the $\mathrm{k}_{\mathrm{i}}$ are rate constants for reaction of $\mathrm{VOC}_{\mathrm{i}}$ with $\mathrm{OH} . \mathrm{Y}_{\mathrm{i}}$ is an $\mathrm{O}_{3}$ yield resulting from the production of peroxy radicals in reaction $(\mathrm{R} 1)$. According to reactions (R2)-(R4), $\mathrm{HO}_{2}, \mathrm{RO}_{2}$, and $\mathrm{RO}_{2}^{\prime}$ radicals yield, respectively 1,2 or $3 \mathrm{O}_{3}$ molecules, and therefore

$$
\mathrm{Y}_{\mathrm{i}}=\alpha+2 \beta+3 \gamma
$$

Equations (1)-(2) have been used by Sillman et al. [1990], Kleinman et al. [1997], Tonnesen and Dennis [2000], and others to study $\mathrm{O}_{3}$ production.

[18] Reaction (1) occurs in competition with

$$
\mathrm{OH}+\mathrm{NO}_{2} \rightarrow \mathrm{HNO}_{3}
$$

$\mathrm{P}\left(\mathrm{NO}_{\mathrm{Z}}\right)$ is approximated as $\mathrm{P}\left(\mathrm{HNO}_{3}\right)$ giving

$$
\mathrm{P}\left(\mathrm{NO}_{\mathrm{z}}\right)=\mathrm{k}_{\mathrm{NO} 2}\left[\mathrm{NO}_{2}\right][\mathrm{OH}] \text {. }
$$

We obtain an expression for $\mathrm{P}\left(\mathrm{O}_{3}\right) / \mathrm{P}\left(\mathrm{NO}_{\mathrm{z}}\right)$ by dividing equation (1) by equation (3),

$$
\mathrm{P}\left(\mathrm{O}_{3}\right) / \mathrm{P}\left(\mathrm{NO}_{\mathrm{z}}\right)=\Sigma \mathrm{Y}_{\mathrm{i}} \mathrm{k}_{\mathrm{i}}\left[\mathrm{VOC}_{\mathrm{i}}\right] / \mathrm{k}_{\mathrm{NO} 2}\left[\mathrm{NO}_{2}\right]
$$

Thus, $\mathrm{P}\left(\mathrm{O}_{3}\right) / \mathrm{P}\left(\mathrm{NO}_{\mathrm{z}}\right)$ is given by a $\mathrm{VOC}$ to $\mathrm{NO}_{2}-\mathrm{OH}$ reactivity ratio. Tonnesen and Dennis [2000] have found that the average $\mathrm{Y}$ for a mixture of VOCs does not vary greatly from place to place so that in many cases it is acceptable to use a single representative value of $\mathrm{Y}$ in equation (4). However, in this study we will use individual $\mathrm{Y}_{\mathrm{i}}$ for each $\mathrm{VOC}_{\mathrm{i}}$ as determined from the stoichiometry of reactions (R2), (R3a), and (R3b) as expressed in the RADM2 [Stockwell et al., 1990] and Paulson and Seinfeld [1992] chemical mechanisms. According to equation (4), $\mathrm{P}\left(\mathrm{O}_{3}\right) / \mathrm{P}\left(\mathrm{NO}_{\mathrm{z}}\right)$ can be obtained from kinetic data and commonly available observations. Leaving aside the question of the approximations that have been made in arriving at equation (4), the accuracy of equation (4) will depend mainly on whether ambient observations capture the total "VOC"-OH reactivity [Lewis et al., 2000].

[19] The most important condition for the applicability of equation (4) is that peroxy radicals formed in reactions (R1) - (R3b) react with $\mathrm{NO}$ rather than with each other or with $\mathrm{OH}$. This will be true at high $\mathrm{NO}_{\mathrm{x}}$ concentrations where radical-radical reactions are not important. It can also be true in situations where peroxide production is important as long as the chain length for $\mathrm{O}_{3}$ formation is high; that is, there is a several-fold greater chance that a peroxy radical will react with NO compared with

$$
\begin{gathered}
\mathrm{HO}_{2}+\mathrm{HO}_{2}\left(\mathrm{RO}_{2}\right) \rightarrow \mathrm{H}_{2} \mathrm{O}_{2}(\mathrm{ROOH}) \\
\mathrm{OH}+\mathrm{HO}_{2} \rightarrow \mathrm{H}_{2} \mathrm{O}+\mathrm{O}_{2} .
\end{gathered}
$$

Although Carpenter et al. [2000] present an approximate formula that takes into account reaction (R6) for a $\mathrm{CO} / \mathrm{CH}_{4}$ atmosphere, in this study we will regard radical combination reactions as a fundamental limitation to obtaining a simple observation based equation for $\mathrm{P}\left(\mathrm{O}_{3}\right) / \mathrm{P}\left(\mathrm{NO}_{\mathrm{z}}\right)$.

[20] Several other approximations have been made in deriving equation (4), which are more or less serious depending on circumstances. We give here two additional formulas for $\mathrm{P}\left(\mathrm{O}_{3}\right) / \mathrm{P}\left(\mathrm{NO}_{\mathrm{z}}\right)$ (equations (5) and (6), below) that incorporate chemical processes that are left out of equation (4). These formulas are not a substitute for equation (4) as they require additional, hard to obtain, observational inputs. They are presented here as an aid to quantifying the errors in equation (4).

[21] Equation (4) does not take into account the role of primary peroxy radicals in forming $\mathrm{O}_{3}$. At high $\mathrm{NO}_{x}$, a primary $\mathrm{HO}_{2}, \mathrm{RO}_{2}$, or $\mathrm{RO}_{2}^{\prime}$ radical (formed mostly from photolysis reactions) will produce either 1,2 , or 3 molecules of $\mathrm{O}_{3}$, respectively, before it enters the $\mathrm{OH}$ cycle represented by reactions (R1) to (R5). A modified version of equation (4) taking this into account is

$$
\begin{aligned}
\mathrm{P}\left(\mathrm{O}_{3}\right) / \mathrm{P}\left(\mathrm{NO}_{\mathrm{z}}\right)= & \Sigma \mathrm{Y}_{\mathrm{i}} \mathrm{k}_{\mathrm{i}}\left[\mathrm{VOC}_{\mathrm{i}}\right] / \mathrm{k}_{\mathrm{NO} 2}\left[\mathrm{NO}_{2}\right]+\left(\mathrm{P}\left(\mathrm{HO}_{2}\right)\right. \\
& \left.+2 \mathrm{P}\left(\mathrm{RO}_{2}\right)+3 \mathrm{P}\left(\mathrm{RO}_{2}^{\prime}\right)\right) / \mathrm{k}_{\mathrm{NO} 2}[\mathrm{OH}]\left[\mathrm{NO}_{2}\right]
\end{aligned}
$$

Note that, in contrast to equation (4), equation (5) is less suited to the analysis of ambient measurements because it depends on $\mathrm{OH}$ radical concentration.

[22] Another approximation made in deriving equation (4) is that $\mathrm{NO}_{\mathrm{x}}$ sinks other than $\mathrm{OH}+\mathrm{NO}_{2}$ have been ignored. Loss of $\mathrm{NO}_{\mathrm{x}}$ by nighttime reactions of $\mathrm{NO}_{3}$ and $\mathrm{N}_{2} \mathrm{O}_{5}$ is not considered because we are interested only in 


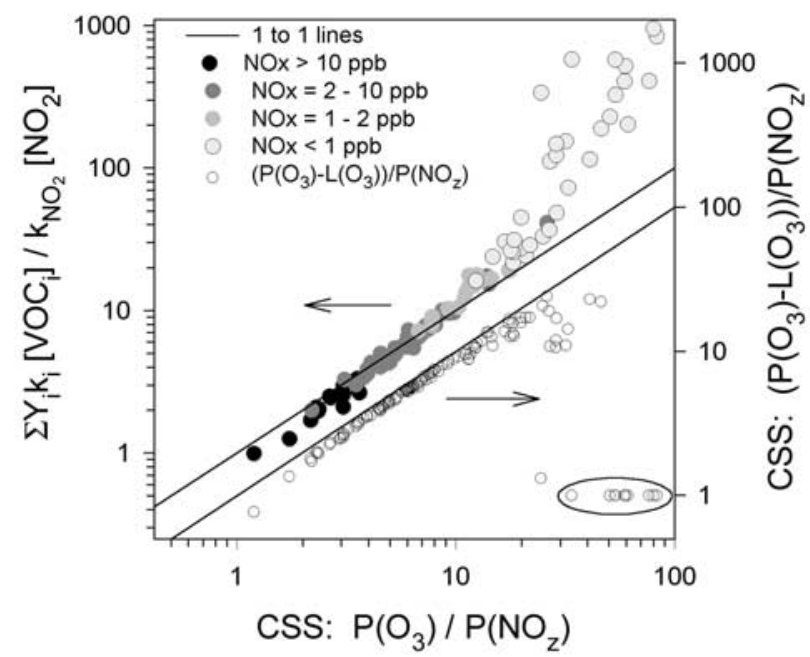

Figure 1. Test of approximate formula for determining the instantaneous $\mathrm{O}_{3}$ production efficiency, $\mathrm{P}\left(\mathrm{O}_{3}\right) / \mathrm{P}\left(\mathrm{NO}_{z}\right)$. Each gray scale circle gives $\mathrm{P}\left(\mathrm{O}_{3}\right) / \mathrm{P}\left(\mathrm{NO}_{\mathrm{z}}\right)$ from a constrained steady state (CSS) calculation based on observed concentrations and from equation (4) based on the same observations. Equation (4) approximates $\mathrm{P}\left(\mathrm{O}_{3}\right) / \mathrm{P}\left(\mathrm{NO}_{\mathrm{z}}\right)$ as a VOC to $\mathrm{NO}_{2}-\mathrm{OH}$ reactivity ratio. Points are shaded according to $\mathrm{NO}_{\mathrm{x}}$ concentration. Information on the importance of $\mathrm{O}_{3}$ loss process is given by the open circles which provide a comparison between CSS values of $\mathrm{P}\left(\mathrm{O}_{3}\right)$ / $\mathrm{P}\left(\mathrm{NO}_{\mathrm{z}}\right)$ and $\left(\mathrm{P}\left(\mathrm{O}_{3}\right)-\mathrm{L}\left(\mathrm{O}_{3}\right)\right) / \mathrm{P}\left(\mathrm{NO}_{\mathrm{z}}\right)$. This comparison uses the scale on the right side of the figure which is displaced for clarity. The open circles enclosed by an ellipse all have negative values of $\left(\mathrm{P}\left(\mathrm{O}_{3}\right)-\mathrm{L}\left(\mathrm{O}_{3}\right)\right) / \mathrm{P}\left(\mathrm{NO}_{\mathrm{z}}\right)$ and are placed on the figure with an arbitrary value of 1 . One to one lines are provided for each comparison.

same-day, daytime-chemistry. As $\mathrm{NO}_{3} / \mathrm{N}_{2} \mathrm{O}_{5}$ reactions can remove a significant fraction of $\mathrm{NO}_{\mathrm{x}}$ from the $\mathrm{O}_{3}$ forming sequence of reactions [Dentener and Crutzen, 1993; Munger et al., 1998], nighttime chemistry must be included in any multiday budget analysis of $\mathrm{O}_{3}$ production [Liu et al., 1987; Lin et al., 1988]. Loss of $\mathrm{NO}_{\mathrm{x}}$ during the daytime by HONO production can also be ignored because of its rapid photolysis. Carpenter et al. [2000] show the importance of $\mathrm{HO}_{2} \mathrm{NO}_{2}$ formation under low $\mathrm{NO}_{\mathrm{x}}$ conditions at a cold high altitude site. This reaction is not significant at the higher temperatures characteristic of the US summer boundary layer.

[23] The two remaining $\mathrm{NO}_{\mathrm{x}}$ sinks which we cannot a priori ignore are formation of PAN and organic nitrates. Organic nitrates are included in the CSS calculations but not in either equation (4) or equation (5). PAN is not included in the CSS calculations on the assumption that it is in steady state and therefore is neither a source nor sink for $\mathrm{NO}_{\mathrm{x}}$. This will on average be true because other sinks of PAN such as $\mathrm{OH}$ oxidation, photolysis, and dry deposition are small so a molecule of $\mathrm{NO}_{\mathrm{x}}$ removed by forming PAN in one location will yield a molecule of $\mathrm{NO}_{\mathrm{x}}$ in another location when PAN dissociates. Lin et al. [1988] used a similar approximation in their calculations which they were able to test, finding that PAN chemistry made only a small change in their calculated ozone production efficiencies. However, we are interested here mainly in the near-source behavior of a plume where there is usually net PAN production. A formal expression that includes additional sinks for $\mathrm{NO}_{\mathrm{x}}$, as well as primary peroxy radicals, can be obtained by multiplying the right hand side of equation (5) by $\mathrm{P}\left(\mathrm{HNO}_{3}\right) / \mathrm{P}\left(\mathrm{NO}_{\mathrm{z}}\right)$, i.e.,

$$
\begin{aligned}
\mathrm{P}\left(\mathrm{O}_{3}\right) / \mathrm{P}\left(\mathrm{NO}_{\mathrm{z}}\right)= & \left\{\Sigma \mathrm{Y}_{\mathrm{i}} \mathrm{k}_{\mathrm{i}}\left[\mathrm{VOC}_{\mathrm{i}}\right] / \mathrm{k}_{\mathrm{NO} 2}\left[\mathrm{NO}_{2}\right]+\left(\mathrm{P}\left(\mathrm{HO}_{2}\right)\right.\right. \\
& \left.\left.+2 \mathrm{P}\left(\mathrm{RO}_{2}\right)+3 \mathrm{P}\left(\mathrm{RO}_{2}^{\prime}\right)\right) / \mathrm{k}_{\mathrm{NO} 2}[\mathrm{OH}]\left[\mathrm{NO}_{2}\right]\right\} \\
& \times \mathrm{P}\left(\mathrm{HNO}_{3}\right) / \mathrm{P}\left(\mathrm{NO}_{\mathrm{z}}\right)
\end{aligned}
$$

\subsection{CSS Calculations for Phoenix}

[24] Figure 1 shows a comparison between $\mathrm{P}\left(\mathrm{O}_{3}\right) / \mathrm{P}\left(\mathrm{NO}_{\mathrm{z}}\right)$ obtained from CSS calculations based on G-1 observations, and the corresponding quantity obtained from the analytic equation (equation (4)). There is good agreement as long as $\mathrm{NO}_{\mathrm{x}}$ concentrations are higher than 1-2 ppb. As $\mathrm{NO}_{\mathrm{x}}$ concentrations drop below $1 \mathrm{ppb}$, equation (4) yields an increasingly large overestimate of $\mathrm{P}\left(\mathrm{O}_{3}\right) / \mathrm{P}\left(\mathrm{NO}_{z}\right)$. Equation (4) is based on the assumption that the primary fate of a peroxy radical is to react with $\mathrm{NO}$, forming $\mathrm{O}_{3}$ in reactions (R2)-(R4). $\mathrm{P}\left(\mathrm{O}_{3}\right)$, and hence $\mathrm{P}\left(\mathrm{O}_{3}\right) / \mathrm{P}\left(\mathrm{NO}_{\mathrm{z}}\right)$, are overestimated because, at low $\mathrm{NO}_{\mathrm{x}}$, the primary fate of a peroxy radical is instead to react in a chain termination step such as reaction (R6) or (R7). CSS calculations for other urban areas, with different chemical environments, indicate that the $\mathrm{NO}_{\mathrm{x}}$ concentration below which equation (4) is not applicable, can be as high as $3-5 \mathrm{ppb}$ in regions with much higher radical production rates and VOC reactivity.

[25] Figure 1 also shows the effect of $\mathrm{O}_{3}$ loss reactions on ozone production efficiency. For $\mathrm{NO}_{\mathrm{x}}$ concentrations between 1 and $10 \mathrm{ppb}, \mathrm{P}\left(\mathrm{O}_{3}\right)$ is about an order of magnitude greater than the $\mathrm{O}_{3}$ loss rate (mainly from photolysis reaction). Therefore $\mathrm{P}\left(\mathrm{O}_{3}\right) / \mathrm{P}\left(\mathrm{NO}_{\mathrm{z}}\right)$ is a good approximation to the net $\mathrm{O}_{3}$ production efficiency, $\left(\mathrm{P}\left(\mathrm{O}_{3}\right)-\mathrm{L}\left(\mathrm{O}_{3}\right)\right) / \mathrm{P}\left(\mathrm{NO}_{\mathrm{z}}\right)$. At low $\mathrm{NO}_{\mathrm{x}}, \mathrm{L}\left(\mathrm{O}_{3}\right)$ has a rate of a few tenths of a ppb $\mathrm{h}^{-1}$, while $\mathrm{P}\left(\mathrm{O}_{3}\right)$ is near zero. As indicated in the figure there is a subset of samples having net $\mathrm{O}_{3}$ destruction. At very high $\mathrm{NO}_{\mathrm{x}},\left(\mathrm{P}\left(\mathrm{O}_{3}\right)-\mathrm{L}\left(\mathrm{O}_{3}\right)\right) / \mathrm{P}\left(\mathrm{NO}_{\mathrm{z}}\right)$ can be several tens of percent lower than $\mathrm{P}\left(\mathrm{O}_{3}\right) / \mathrm{P}\left(\mathrm{NO}_{\mathrm{z}}\right)$ because some of these samples also have a low $\mathrm{P}\left(\mathrm{O}_{3}\right)$.

[26] A quantitative comparison between the CSS results and the three approximate analytic formulas for $\mathrm{P}\left(\mathrm{O}_{3}\right)$ / $\mathrm{P}\left(\mathrm{NO}_{\mathrm{z}}\right)$ is given in Table 2. Results are presented as percent error with a positive number meaning that the analytic

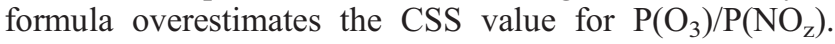

\begin{tabular}{|c|c|c|c|}
\hline \multirow[b]{2}{*}{$\mathrm{NO}_{\mathrm{x}}, \mathrm{ppb}$} & \multicolumn{3}{|c|}{ Percent Error } \\
\hline & $\begin{array}{c}\text { Equation (4) } \\
\text { VOC/NO } \\
\text { Reactivity Ratio }\end{array}$ & $\begin{array}{c}\text { Equation (5): } \\
\text { Equation (4) }+ \\
\text { Primary } \mathrm{HO}_{2}, \mathrm{RO}_{2} \\
\end{array}$ & $\begin{array}{c}\text { Equation (6): } \\
\text { Equation (5) }+ \\
\text { Other } \mathrm{NO}_{\mathrm{z}} \text { Sinks } \\
\end{array}$ \\
\hline$>10$ & -16 & 4 & 1 \\
\hline $2-10$ & -1 & 10 & 3 \\
\hline $1-2$ & 18 & 28 & 17 \\
\hline$<1$ & 220 & 275 & 142 \\
\hline
\end{tabular}

Table 2. Average Percent Error of Analytic Formulas in Predicting $\mathrm{P}\left(\mathrm{O}_{3}\right) / \mathrm{P}\left(\mathrm{NO}_{\mathrm{z}}\right)$ for Phoenix G-1 Data Set 


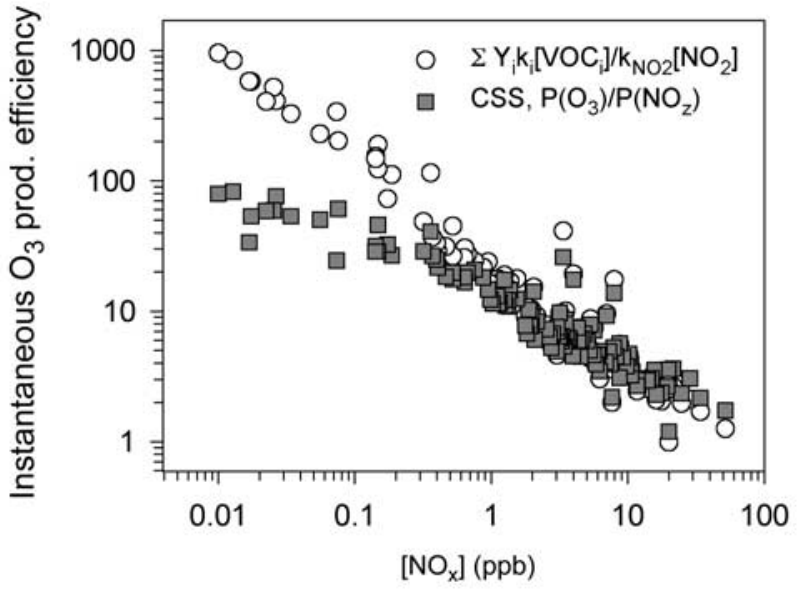

Figure 2. Dependence of instantaneous $\mathrm{O}_{3}$ production efficiency, $\mathrm{P}\left(\mathrm{O}_{3}\right) / \mathrm{P}\left(\mathrm{NO}_{z}\right)$, on $\mathrm{NO}_{\mathrm{x}}$ concentration, from CSS calculation and from the approximate equation, (equation (4)), which is a VOC to $\mathrm{NO}_{2}-\mathrm{OH}$ reactivity ratio.

For all three formulas the trend is toward more of an overestimate as $\mathrm{NO}_{\mathrm{x}}$ concentrations decrease, due to the assumption that peroxy radicals all react with NO. Results from equation (6) indicate the importance of alternate radical termination reactions, since their neglect is the major approximation in that equation. Equation (4) which presents $\mathrm{P}\left(\mathrm{O}_{3}\right) / \mathrm{P}\left(\mathrm{NO}_{z}\right)$ as a simple $\mathrm{VOC}$ to $\mathrm{NO}_{2}$ reactivity ratio gives satisfactory results for $\mathrm{NO}_{\mathrm{x}}>1 \mathrm{ppb}$, as already demonstrated in Figure 1. Equation (5) includes $\mathrm{O}_{3}$ formation from primary peroxy radicals which increases $\mathrm{P}\left(\mathrm{O}_{3}\right) / \mathrm{P}\left(\mathrm{NO}_{\mathrm{z}}\right)$ by $10-20 \%$, for $\mathrm{NO}_{\mathrm{x}}>1 \mathrm{ppb}$. Adding alternate $\mathrm{NO}_{\mathrm{z}}$ sinks in equation (6) reduces $\mathrm{P}\left(\mathrm{O}_{3}\right) / \mathrm{P}\left(\mathrm{NO}_{\mathrm{z}}\right)$ by $3-11 \%$, again for $\mathrm{NO}_{\mathrm{x}}>1 \mathrm{ppb}$. PAN formation is not included in the CSS calculations which minimizes the error due to approximating $\mathrm{P}\left(\mathrm{NO}_{\mathrm{z}}\right)$ as equal to $\mathrm{P}\left(\mathrm{HNO}_{3}\right)$.

[27] The gray scale coding in Figure 1 shows that values of $\mathrm{P}\left(\mathrm{O}_{3}\right) / \mathrm{P}\left(\mathrm{NO}_{\mathrm{z}}\right)$, from both $\mathrm{CSS}$ calculations and equation (4), increase at low $\mathrm{NO}_{\mathrm{x}}$ concentration. This is a familiar result dating back to the seminal paper of Liu et al. [1987] that showed that $\mathrm{O}_{3}$ is produced more efficiently at low $\mathrm{NO}_{\mathrm{x}}$. The relation between $\mathrm{P}\left(\mathrm{O}_{3}\right) / \mathrm{P}\left(\mathrm{NO}_{\mathrm{z}}\right)$ and $\mathrm{NO}_{\mathrm{x}}$ concentration is explicitly shown in Figure 2. Both the CSS calculation and approximate formula indicate that $\mathrm{P}\left(\mathrm{O}_{3}\right)$ / $\mathrm{P}\left(\mathrm{NO}_{z}\right)$ increases as $\mathrm{NO}_{\mathrm{x}}$ decreases. At a $\mathrm{NO}_{\mathrm{x}}$ concentration of $1 \mathrm{ppb}$, the approximate formula overestimates $\mathrm{P}\left(\mathrm{O}_{3}\right) /$ $\mathrm{P}\left(\mathrm{NO}_{\mathrm{z}}\right)$ by about $30 \%$. Below a few hundred ppt, radical loss due to peroxide formation (R6) becomes greater than chain propagation reactions $(\mathrm{R} 2),(\mathrm{R} 3 \mathrm{a})$, and $(\mathrm{R} 3 \mathrm{~b})$ and the overestimate becomes very large rendering the approximate formula no longer useful, even in a qualitative sense.

[28] Figure 3 gives the $\mathrm{NO}_{x}$ dependence of net $\mathrm{O}_{3}$ production, $\left(\mathrm{P}\left(\mathrm{O}_{3}\right)-\mathrm{L}\left(\mathrm{O}_{3}\right)\right) / \mathrm{P}\left(\mathrm{NO}_{\mathrm{z}}\right)$. As in the preceding graphs, each data point corresponds to a time and location where a VOC sample was obtained. Several data subsets are identified in this figure. Four points identified on the figure as "VOC outliers" are well above the main grouping. Observations corresponding to these samples were taken on different days, but two are in the same location and are evidently affected by local emissions with a high
VOC to $\mathrm{NO}_{\mathrm{x}}$ ratio. Initial conditions for the Lagrangian calculations described below are defined as an average over six sample points identified in the figure. Most of the Phoenix samples follow a well-defined trend with a peak net $\mathrm{O}_{3}$ production efficiency of 22 occurring at a $\mathrm{NO}_{x}$ concentration of $\sim 0.3 \mathrm{ppb}$. The amount of $\mathrm{O}_{3}$ produced at such a high efficiency is limited by the availability of $\mathrm{NO}_{\mathrm{x}}$. A transition from net $\mathrm{O}_{3}$ production to net destruction occurs at $\mathrm{NO}_{\mathrm{x}}$ concentrations of about $80 \mathrm{ppt}$, a value that depends on chemical and meteorological conditions, but is in line with literature estimates [e.g., Liu et al., 1992; Ehhalt, 1999].

\subsection{Lagrangian Model Results for Phoenix}

[29] A Lagrangian model was used to examine the time evolution of the Phoenix urban plume. Calculations show how chemical reaction and dilution of plume air with clean background air effects VOC reactivity and $\mathrm{NO}_{2}$ concentration and therefore by equation (4) determines the time evolution of $\mathrm{P}\left(\mathrm{O}_{3}\right) / \mathrm{P}\left(\mathrm{NO}_{\mathrm{z}}\right)$.

[30] Time dependent Lagrangian calculations were initialized at 10:00 LST using the chemical concentrations summarized in Table 3. This set of concentrations is an average derived from six representative morning VOC samples collected over downtown Phoenix (see also Figure 3 ). Calculations were performed with and without dilution of the plume with clean background. The composition of background air is also given in Table 3 .

[31] Figure 4a shows the time evolution of $\mathrm{NO}_{2}$ concentration and VOC reactivity for the no-dilution case. Both $\left[\mathrm{NO}_{2}\right]$ and $\mathrm{VOC}$ reactivity decrease with time primarily due to reaction with $\mathrm{OH}$ radical. Each VOC reacts with $\mathrm{OH}$ with its own characteristic rate constant, $\mathrm{k}_{\mathrm{i}}$. An effective rate constant, $\mathrm{k}_{\mathrm{EFF}}$, describing the decay in the

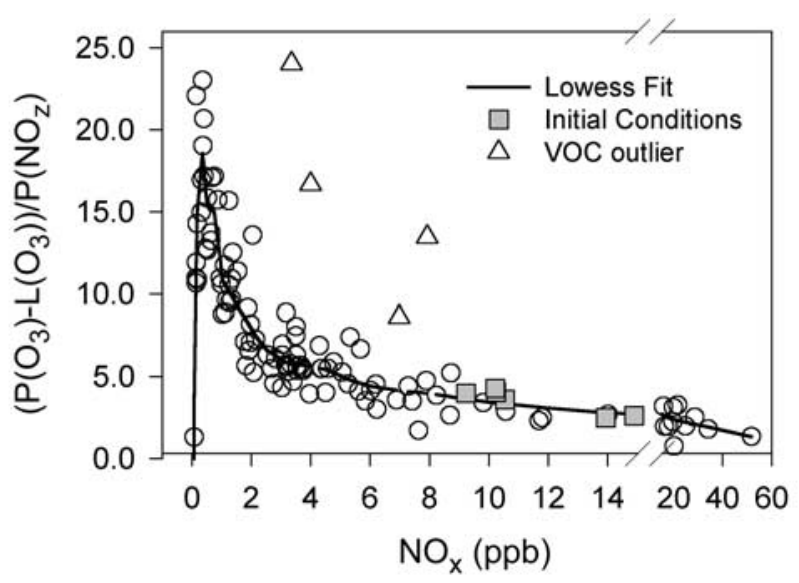

Figure 3. CSS calculations of $\left(\mathrm{P}\left(\mathrm{O}_{3}\right)-\mathrm{L}\left(\mathrm{O}_{3}\right)\right) / \mathrm{P}\left(\mathrm{NO}_{\mathrm{z}}\right)$ versus $\mathrm{NO}_{\mathrm{x}}$ concentration. Ten points with negative values of $\left(\mathrm{P}\left(\mathrm{O}_{3}\right)-\mathrm{L}\left(\mathrm{O}_{3}\right)\right) / \mathrm{P}\left(\mathrm{NO}_{\mathrm{z}}\right)$ and $\mathrm{NO}_{\mathrm{x}}$ below 75 ppt are not shown on graph. Solid line is a Lowess (locally weighted regression scatterplot smoothing) fit to data points [Cleveland and Devlin, 1988], omitting the four points identified as VOC outliers. Initial conditions for Lagrangian calculations (see text) are averages over six samples identified by solid symbol. 
Table 3. Initial Conditions and Chemical Composition of Background Air for Time Dependent Lagrangian Calculations ${ }^{\mathrm{a}}$

\begin{tabular}{|c|c|c|}
\hline \multirow[b]{2}{*}{ Species } & \multicolumn{2}{|c|}{ Concentration, ppb } \\
\hline & Initial Conditions & Background \\
\hline $\mathrm{O}_{3}$ & 61 & 44 \\
\hline $\mathrm{NO}_{\mathrm{x}}$ & 11.5 & 0.03 \\
\hline $\mathrm{CH}_{4}$ & 1750 & 1750 \\
\hline $\mathrm{CO}$ & 310 & 120 \\
\hline $\mathrm{HCHO}$ & 2.2 & 0.6 \\
\hline $\mathrm{H}_{2} \mathrm{O}_{2}$ & 0.9 & 1.6 \\
\hline \multirow[t]{2}{*}{ Organic peroxides } & 0.6 & 0.0 \\
\hline & \multicolumn{2}{|c|}{ VOC Reactivity, $\mathrm{s}^{-1 \mathrm{~b}}$} \\
\hline Species & Initial Conditions & Background \\
\hline Anthropogenic NMHCs & 1.3 & 0.02 \\
\hline Biogenic hydrocarbons & 0.1 & 0.0 \\
\hline
\end{tabular}

${ }^{\mathrm{a}}$ Other conditions: Temperature $=21^{\circ} \mathrm{C}$; Altitude $=940 \mathrm{~m}$; Dew point $=$ $1{ }^{\circ} \mathrm{C}$

${ }^{\mathrm{b}}$ Reactivity $=\Sigma \mathrm{k}_{\mathrm{i}}\left[\mathrm{VOC}_{\mathrm{i}}\right]$.

initial VOC reactivity due to $\mathrm{OH}$ oxidation reactions can be defined by

$$
\mathrm{d} \text { Reactivity } / \mathrm{dt}=-\mathrm{k}_{\mathrm{EFF}}[\mathrm{OH}] \text { Reactivity }
$$

where

$$
\begin{gathered}
\text { Reactivity }=\Sigma \mathrm{k}_{\mathrm{i}} \mathrm{Y}_{\mathrm{i}}\left[\mathrm{VOC}_{\mathrm{i}}\right] \\
\mathrm{k}_{\mathrm{EFF}}=\Sigma \mathrm{k}_{\mathrm{i}}^{2} \mathrm{Y}_{\mathrm{i}}\left[\mathrm{VOC}_{\mathrm{i}}\right] / \Sigma \mathrm{k}_{\mathrm{i}} \mathrm{Y}_{\mathrm{i}}\left[\mathrm{VOC}_{\mathrm{i}}\right] .
\end{gathered}
$$

It can be shown that, according to equation (4), the condition for $\mathrm{P}\left(\mathrm{O}_{3}\right) / \mathrm{P}\left(\mathrm{NO}_{\mathrm{z}}\right)$ increasing with time due to oxidation reactions is,

$$
\mathrm{k}_{\mathrm{EFF}}<\mathrm{k}_{\mathrm{NO} 2} \text {. }
$$

Although equations (7)-(10) do not take into account the reactivity of VOC reaction products (which are taken into account in the Lagrangian calculations), it provides a qualitative rationale for time dependent changes in ozone production efficiency. As an air parcel ages, reaction with $\mathrm{OH}$ selectively removes the more reactive VOCs, and $\mathrm{k}_{\mathrm{EFF}}$ decreases. The rate constant for reaction of $\mathrm{NO}_{2}$ with $\mathrm{OH}$, in contrast, does not change. At the start of the Lagrangian calculation $\mathrm{k}_{\mathrm{EFF}}$ is a factor of 1.6 times greater than $\mathrm{k}_{\mathrm{NO} 2}$. After 1 hour, the more reactive VOCs have decreased to the point that $\mathrm{k}_{\mathrm{EFF}}$ is slightly less than $\mathrm{k}_{\mathrm{NO} 2}$. At later times, most of the fast reacting VOCs have disappeared leaving behind less reactive alkanes, $\mathrm{CO}$, and $\mathrm{CH}_{4}$. Then, $\mathrm{k}_{\mathrm{EFF}}$ is less than half of $\mathrm{k}_{\mathrm{NO} 2}$. Figure $4 \mathrm{~b}$ shows the time evolution of the $\mathrm{VOC}$ to $\mathrm{NO}_{2}-\mathrm{OH}$ reactivity ratio [i.e., equation (4)], which aside from a scale factor is identical to the ratio of the two curves shown in Figure 4a. For comparison we provide values of $\mathrm{P}\left(\mathrm{O}_{3}\right) / \mathrm{P}\left(\mathrm{NO}_{\mathrm{z}}\right)$, determined from the same time dependent calculation. As in Figure 1, we see that the $\mathrm{OH}$ reactivity ratio [i.e., equation (4)] is a reasonable approximation to OPE. The inclusion of PAN chemistry in the Lagrangian calculations only slightly affects the agreement between equation (4) and $\left.\mathrm{P}\left(\mathrm{O}_{3}\right) / \mathrm{P}_{(} \mathrm{NO}_{\mathrm{z}}\right)$. Figure $4 \mathrm{~b}$ also shows that, except for a short period before the most reactive VOCs have been depleted, chemical reactions cause OPE to increase with time due to the circumstance that $\mathrm{NO}_{2}$ is more reactive than the average VOC.

[32] Figures $5 \mathrm{a}$ and $5 \mathrm{~b}$ present the corresponding results for a calculation in which plume air is diluted by cleaner background air at a rate of 0.2 hour $^{-1}$. Dilution increases the rate at which $\mathrm{NO}_{2}$ and $\mathrm{VOC}$ reactivity are removed. $\mathrm{NO}_{2}$ is affected more than VOC reactivity because background air has significant VOC reactivity from $\mathrm{CO}$ and $\mathrm{CH}_{4}$ but contains very little $\mathrm{NO}_{\mathrm{x}}$. Dilution results in a higher value of the $\mathrm{VOC}$ to $\mathrm{NO}_{2}$ reactivity ratio and hence an increase in $\mathrm{O}_{3}$ production efficiency relative to the no dilution case.

[33] Lagrangian model results for the dependence of $\left(\mathrm{P}\left(\mathrm{O}_{3}\right)-\mathrm{L}\left(\mathrm{O}_{3}\right)\right) / \mathrm{P}\left(\mathrm{NO}_{\mathrm{z}}\right)$ on $\mathrm{NO}_{\mathrm{x}}$ are shown in Figure 6. Included in Figure 6 is the Lowess (locally weighted regression scatterplot smoothing) fit to the CSS results shown in Figure 3. The Lagrangian results are displaced slightly from the Lowess fit but are well within the scatter of the individual CSS points. Figure 6 shows that the time evolution of an air parcel, with or without dilution, produces a sequence of atmospheric states (as judged by OPE and $\mathrm{NO}_{\mathrm{x}}$ concentration) that are similar to those observed within the ensemble of our measurements.

[34] It is not at all obvious that CSS and Lagrangian results should be so similar. The Lagrangian calculations give us information on concentration changes in an evolving air mass. In contrast, the observed data points are a collection of 123 snapshots taken of atmospheric composition in the Phoenix air basin. These observations are spread
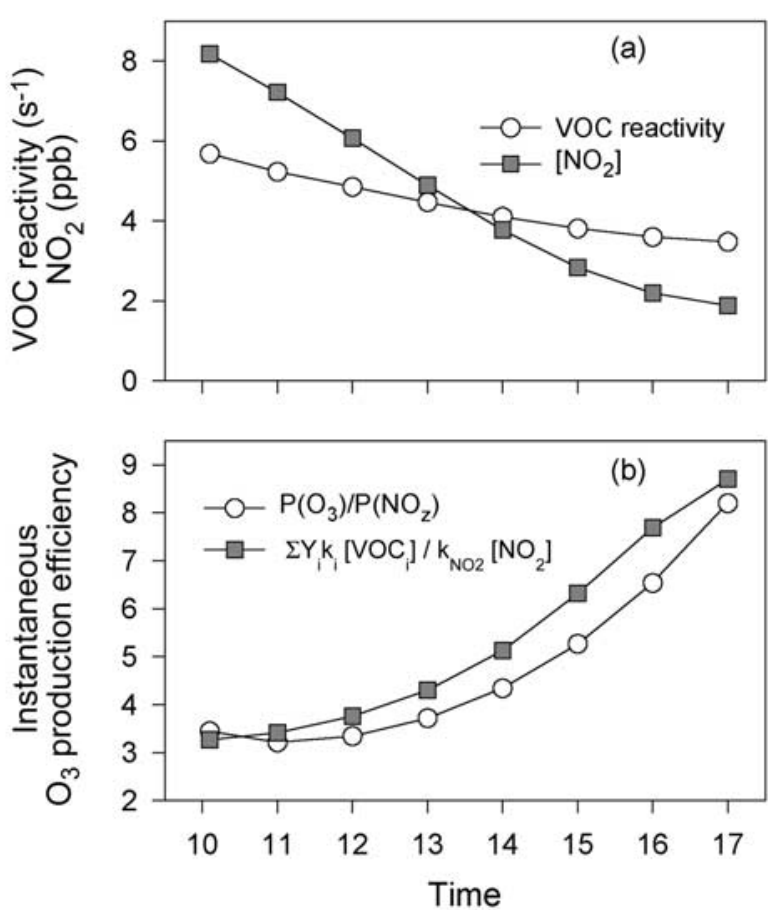

Figure 4. Results from Lagrangian model calculation without dilution. Initial conditions are given in Table 3. (a) $\mathrm{NO}_{2}$ concentration and VOC reactivity, $\Sigma \mathrm{Y}_{\mathrm{i}} \mathrm{k}_{\mathrm{i}}\left[\mathrm{VOC}_{\mathrm{i}}\right]$. (b) Instantaneous ozone production efficiency determined from model as $\mathrm{P}\left(\mathrm{O}_{3}\right) / \mathrm{P}\left(\mathrm{NO}_{\mathrm{z}}\right)$ and as $\Sigma \mathrm{Y}_{\mathrm{i}} \mathrm{k}_{\mathrm{i}}\left[\mathrm{VOC}_{\mathrm{i}}\right] / \mathrm{k}_{\mathrm{NO} 2}\left[\mathrm{NO}_{2}\right]$. 

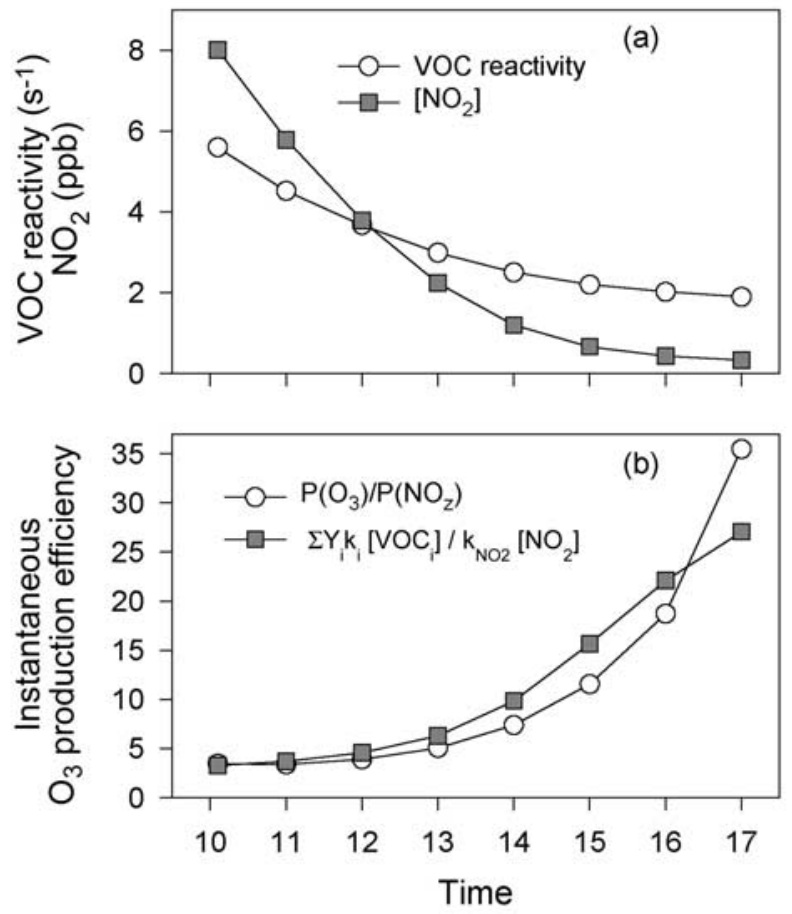

Figure 5. Results from Lagrangian model calculation with dilution of plume air with background air at a rate of 0.2 hour $^{-1}$. Initial conditions and composition of background air given in Table 3. Same format as Figure 4.

over 20 flights, in the morning and afternoon, at varying altitude, and at various distances from the downtown source region. Our results indicate that these snapshots occupy a region of OPE- $\mathrm{NO}_{\mathrm{x}}$ parameter space similar to that expected from the time evolution of a single air mass. Such a relation would not be expected if the Phoenix area contained a wide range of emission sources with very different $\mathrm{VOC}$ to $\mathrm{NO}_{\mathrm{x}}$ ratios. For example, samples taken in the plume of a large $\mathrm{NO}_{\mathrm{x}}$ emitter, such as a power plant, would be expected to contribute points below the main grouping. The one set of points which are conspicuously off of the main sequence (see Figure 3) appear to be caused by an atypical emission source with a high VOC to $\mathrm{NO}_{\mathrm{x}}$ ratio. The similarity between the Lagrangian calculations and the ensemble of observed data points is due to the circumstance that there is a single dominate emissions category, namely mobile sources, with a restricted range of $\mathrm{VOC}$ to $\mathrm{NO}_{\mathrm{x}}$ emission ratios. $\mathrm{NO}_{\mathrm{x}}$ point sources and biogenic emissions are relatively small in Phoenix [Heisler et al., 1997].

\section{Photochemistry With Transport}

[35] We have been concerned so far with the instantaneous rates at which $\mathrm{O}_{3}$ is being formed and $\mathrm{NO}_{\mathrm{x}}$ removed. In order to make a connection between the instantaneous theory and observed concentrations, we consider the total amounts of $\mathrm{O}_{3}$ and $\mathrm{NO}_{\mathrm{x}}$ oxidation products produced as a plume is transported away from its source region. Concentration changes (i.e., $\Delta$ in the notation below) are defined in the Lagrangian framework as a downwind concentration minus the concentration that existed in the same air mass at an earlier time upwind of an emission source. Section 7 discusses measurements in the Phoenix urban plume where $\Delta$ refers to spatial changes.

\subsection{The $\mathrm{n}$ - 1 Effect}

[36] As $\mathrm{NO}_{\mathrm{x}}$ emissions are primarily $\mathrm{NO}$, each molecule of $\mathrm{NO}_{\mathrm{x}}$ added to the atmosphere has the eventual consequence of removing one molecule of $\mathrm{O}_{3}$ by $\mathrm{NO}+\mathrm{O}_{3} \rightarrow$ $\mathrm{NO}_{2} ; \mathrm{NO}_{2} \rightarrow$ oxidation product (assuming that $\mathrm{NO}_{\mathrm{x}}$ is lost exclusively through $\mathrm{NO}_{2}$ ). This loss of an $\mathrm{O}_{3}$ molecule must be taken into account when relating $\Delta \mathrm{O}_{\mathrm{x}} / \Delta \mathrm{NO}_{\mathrm{z}}$ to $\mathrm{P}\left(\mathrm{O}_{3}\right) / \mathrm{P}\left(\mathrm{NO}_{\mathrm{z}}\right)$. It gives rise to what we call the " $\mathrm{n}-1$ effect" whereby an air mass with a constant $\mathrm{P}\left(\mathrm{O}_{3}\right) /$ $\mathrm{P}\left(\mathrm{NO}_{\mathrm{z}}\right)$ of $\mathrm{n}$ yields an overall efficiency, $\Delta \mathrm{O}_{\mathrm{x}} / \Delta \mathrm{NO}_{\mathrm{z}}$, of $\mathrm{n}-1$ at all points in the plumes time evolution. By the time that most of the initial $\mathrm{NO}_{\mathrm{x}}$ has been converted to $\mathrm{NO}_{\mathrm{z}}$, $\Delta \mathrm{O}_{3} / \Delta \mathrm{NO}_{\mathrm{z}}$ also approaches $\mathrm{n}-1$. The difference between $\mathrm{n}$ and $\mathrm{n}-1$ is relatively small in low $\mathrm{NO}_{\mathrm{x}}$ cases where ozone production efficiencies can be 10 or greater. It is, however, of considerable importance in more polluted conditions such as in Phoenix or in power plant plumes where efficiencies are less than 5 and sometimes of order unity. Table 4 illustrates the n-1 effect by showing the concentrations of $\mathrm{O}_{3}, \mathrm{NO}_{2}, \mathrm{O}_{\mathrm{x}}$, and $\mathrm{NO}_{\mathrm{z}}$ at three locations; before the plume, at the start of the plume, and after all $\mathrm{NO}_{2}$ has been oxidized.

\subsection{Dependence of $\Delta \mathrm{O}_{\mathrm{x}} / \Delta \mathrm{NO}_{\mathrm{z}}$ on $\left(\mathrm{P}\left(\mathrm{O}_{3}\right)=\mathrm{L}\left(\mathrm{O}_{3}\right)\right) /$ $\mathrm{P}\left(\mathrm{NO}_{\mathrm{z}}\right)$}

[37] The total amount of $\mathrm{O}_{\mathrm{x}}$ and $\mathrm{NO}_{z}$ formed in a plume is a complicated function of the plume's history. In order to show the relation between an instantaneous measure of efficiency, $\left(\mathrm{P}\left(\mathrm{O}_{3}\right)-\mathrm{L}\left(\mathrm{O}_{3}\right)\right) / \mathrm{P}\left(\mathrm{NO}_{\mathrm{z}}\right)$, and an integrated measure, $\Delta \mathrm{O}_{\mathrm{x}} / \Delta \mathrm{NO}_{\mathrm{z}}$, we consider an idealized case in which there is no mixing, dilution, or downwind emissions. The plume starts at an initial time $\mathrm{t}_{0}$ with $\mathrm{NO}_{\mathrm{x}}\left(\mathrm{t}_{0}\right)$ which is equal to the initial $\mathrm{NO}_{\mathrm{y}}$. Changes in $\mathrm{O}_{3}$ will be measured

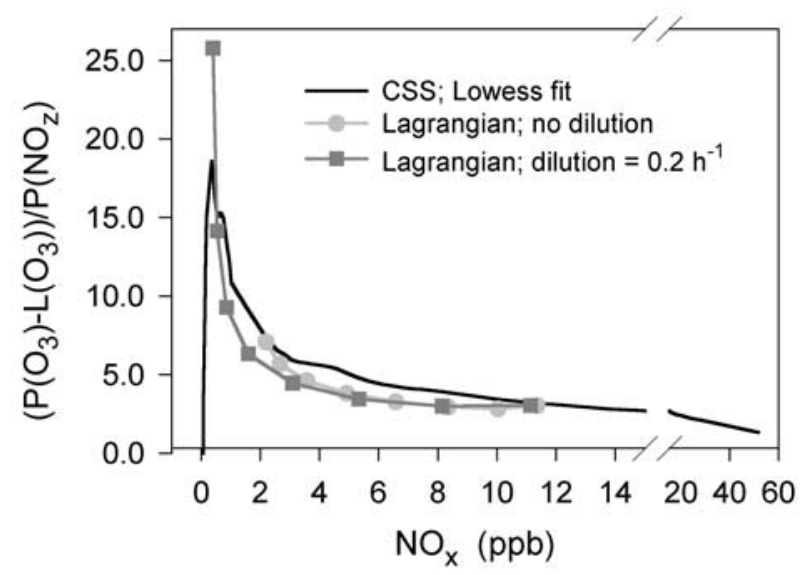

Figure 6. Instantaneous net $\mathrm{O}_{3}$ production efficiency, $\left(\mathrm{P}\left(\mathrm{O}_{3}\right)-\mathrm{L}\left(\mathrm{O}_{3}\right)\right) / \mathrm{P}\left(\mathrm{NO}_{\mathrm{z}}\right)$, versus $\mathrm{NO}_{\mathrm{x}}$ from Lagrangian calculations with and without dilution. Symbols give Lagrangian results at 1-hour intervals. Lagrangian results are compared with the Lowess fit to CSS calculations shown in Figure 3. 


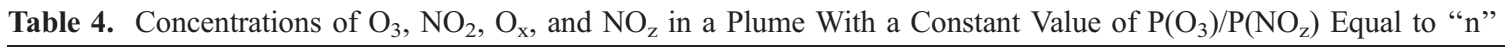

\begin{tabular}{|c|c|c|c|c|}
\hline Location & $\mathrm{O}_{3}$ & $\mathrm{NO}_{2}$ & $\mathrm{O}_{\mathrm{x}}$ & $\mathrm{NO}_{\mathrm{z}}$ \\
\hline Before plume & $\mathrm{O}_{3}\left(\mathrm{t}_{0}\right)$ & 0 & $\mathrm{O}_{3}\left(\mathrm{t}_{0}\right)$ & 0 \\
\hline Start of plume & $\mathrm{O}_{3}\left(\mathrm{t}_{0}\right)-\mathrm{NO}_{2}\left(\mathrm{t}_{0}\right)$ & $\mathrm{NO}_{2}\left(\mathrm{t}_{0}\right)$ & $\mathrm{O}_{3}\left(\mathrm{t}_{0}\right)$ & 0 \\
\hline After reaction $^{a}$ & $\mathrm{O}_{3}\left(\mathrm{t}_{0}\right)+(\mathrm{n}-1) \mathrm{NO}_{2}\left(\mathrm{t}_{0}\right)$ & 0 & $\mathrm{O}_{3}\left(\mathrm{t}_{0}\right)+(\mathrm{n}-1) \mathrm{NO}_{2}\left(\mathrm{t}_{0}\right)$ & $\mathrm{NO}_{2}\left(\mathrm{t}_{0}\right)$ \\
\hline
\end{tabular}

${ }^{a}$ Reaction produces $n$ molecules of $\mathrm{O}_{3}$ for each molecule of $\mathrm{NO}_{2}$ oxidized. The concentration of $\mathrm{O}_{\mathrm{x}}$ is reduced by loss of $\mathrm{NO}_{2}$ and increased by gain of $\mathrm{n} \times \mathrm{NO}_{2}$ resulting in a net gain of $\mathrm{n}-1$ molecules of $\mathrm{O}_{\mathrm{x}}$ for each $\mathrm{NO}_{\mathrm{z}}$ formed.

relative to a background value, $\mathrm{O}_{3}\left(\mathrm{t}_{0}\right)$, that exists just before $\mathrm{NO}_{\mathrm{x}}$ (all in the form of $\mathrm{NO}$ ) is added to the air mass. At a later time " $\mathrm{t}$ " some $\mathrm{NO}_{\mathrm{x}}$ has been oxidized and some $\mathrm{O}_{3}$ has been formed. The increase in $\mathrm{O}_{3}$ is given by

$$
\Delta \mathrm{O}_{3}=\int_{\mathrm{NO}_{\mathbf{x}}\left(\mathrm{t}_{0}\right)}^{\mathrm{NO}_{\mathrm{x}}(\mathrm{t})}\left(\mathrm{P}\left(\mathrm{O}_{3}\right)-\mathrm{L}\left(\mathrm{O}_{3}\right)\right) / \mathrm{P}\left(\mathrm{NO}_{\mathrm{z}}\right) \mathrm{dNO}_{\mathrm{x}}-\left[\mathrm{NO}_{\mathrm{x}}\left(\mathrm{t}_{0}\right)-\mathrm{NO}(\mathrm{t})\right] .
$$

Note that the change in $\mathrm{O}_{3}$ includes a contribution due to titration equal in magnitude to the initial $\mathrm{NO}$ emitted less the $\mathrm{NO}$ at time t. The increase in $\mathrm{O}_{\mathrm{x}}$ is given by

$$
\Delta \mathrm{O}_{\mathrm{x}}=\mathrm{O}_{3}(\mathrm{t})+\mathrm{NO}_{2}(\mathrm{t})-\mathrm{O}_{3}\left(\mathrm{t}_{0}\right) \equiv \Delta \mathrm{O}_{3}+\mathrm{NO}_{2}(\mathrm{t})
$$

assuming that $\mathrm{NO}_{2}=0$ in background air. We add $\mathrm{NO}_{2}(\mathrm{t})$ to both sides of equation (11); use the relations $\mathrm{NO}_{\mathrm{x}}=\mathrm{NO}+$ $\mathrm{NO}_{2}$ and $\Delta \mathrm{NO}_{\mathrm{z}}=\mathrm{NO}_{\mathrm{x}}\left(\mathrm{t}_{0}\right)-\mathrm{NO}_{\mathrm{x}}(\mathrm{t})$; and divide both sides of equation (11) by $\Delta \mathrm{NO}_{\mathrm{z}}$, to obtain:

$$
\Delta \mathrm{O}_{\mathrm{x}} / \Delta \mathrm{NO}_{\mathrm{z}}=\left(1 / \Delta \mathrm{NO}_{\mathrm{z}}\right) \int_{\mathrm{NO}_{\mathbf{x}}\left(\mathrm{t}_{\mathrm{t}}\right)}^{\mathrm{NO}_{\mathrm{x}}(\mathrm{t})}\left(\mathrm{P}\left(\mathrm{O}_{3}\right)-\mathrm{L}\left(\mathrm{O}_{3}\right)\right) / \mathrm{P}\left(\mathrm{NO}_{\mathrm{z}}\right) \mathrm{dNO}_{\mathrm{x}}-1 .
$$

The integral in equations (11) and (13) is simply the area under the curve in Figure 3 bounded on the sides by $\mathrm{NO}_{\mathrm{y}}(\mathrm{t})$ (which is equal to $\mathrm{NO}_{\mathrm{x}}\left(\mathrm{t}_{0}\right)$ because $\mathrm{NO}_{\mathrm{y}}$ is conserved) and $\mathrm{NO}_{\mathrm{x}}(\mathrm{t})$. Thus, for this idealized case $\Delta \mathrm{O}_{\mathrm{x}} / \Delta \mathrm{NO}_{\mathrm{z}}$ can be determined from a knowledge of $\left(\mathrm{P}\left(\mathrm{O}_{3}\right)-\mathrm{L}\left(\mathrm{O}_{3}\right)\right) / \mathrm{P}\left(\mathrm{NO}_{\mathrm{z}}\right)$ as a function of $\mathrm{NO}_{\mathrm{x}}$ and a downwind measurement of $\mathrm{NO}_{\mathrm{x}}(\mathrm{t})$ and $\mathrm{NO}_{\mathrm{y}}(\mathrm{t})$.

[38] Equation (13) is only qualitatively useful as in a realistic setting there is diffusion, dry deposition, and downwind emissions. Also, for many regions there are a diversity of emission sources so a single OPE relation such as shown in Figure $4 \mathrm{~b}$ is not applicable. Nevertheless (13) does contain useful information. It suggests that $\Delta \mathrm{O}_{\mathrm{x}} /$ $\Delta \mathrm{NO}_{\mathrm{z}}$ will have a value intermediate between the instantaneous $\left(\mathrm{P}\left(\mathrm{O}_{3}\right)-\mathrm{L}\left(\mathrm{O}_{3}\right)\right) / \mathrm{P}\left(\mathrm{NO}_{\mathrm{z}}\right)$ calculated downwind and that calculated in the source region. In as much as $\mathrm{P}\left(\mathrm{O}_{3}\right) /$ $\mathrm{P}\left(\mathrm{NO}_{\mathrm{z}}\right)$ can be approximated by a VOC to $\mathrm{NO}_{2}$ reactivity ratio (see equation (4) and Figure 1) which evolves in time in a predictable way, an equation such as equation (13) can provide a link between $\mathrm{VOC}$ and $\mathrm{NO}_{\mathrm{x}}$ emissions and $\mathrm{O}_{3}$ production efficiency.

[39] There is a feature of equation (13) which carries over quantitatively to the more realistic problem that includes diffusion and downwind emissions. We have verified by numerical examples that a scale change in $\left(\mathrm{P}\left(\mathrm{O}_{3}\right)-\mathrm{L}\left(\mathrm{O}_{3}\right)\right) /$ $\mathrm{P}\left(\mathrm{NO}_{\mathrm{z}}\right)$ causes a scale change in $\Delta \mathrm{O}_{\mathrm{x}} / \Delta \mathrm{NO}_{\mathrm{z}}$. For example a doubling of $\left(\mathrm{P}\left(\mathrm{O}_{3}\right)-\mathrm{L}\left(\mathrm{O}_{3}\right)\right) / \mathrm{P}\left(\mathrm{NO}_{\mathrm{z}}\right)$ for all $\mathrm{NO}_{\mathrm{x}}$ values will yield

$$
\Delta \mathrm{O}_{\mathrm{x}} / \Delta \mathrm{NO}_{\mathrm{z}}(\text { doubled })=2 \Delta \mathrm{O}_{\mathrm{x}} / \Delta \mathrm{NO}_{\mathrm{z}}(\text { before doubling })+1 .
$$

Equation (14) is useful in ascribing region to region differences in $\Delta \mathrm{O}_{\mathrm{x}} / \Delta \mathrm{NO}_{\mathrm{z}}$ to differences in $\mathrm{P}\left(\mathrm{O}_{3}\right) / \mathrm{P}\left(\mathrm{NO}_{\mathrm{z}}\right)$, which in turn can be ascribed to differences in VOC to $\mathrm{NO}_{2}$ reactivity ratios and ultimately to differences in emissions [Kleinman et al., 2002].

\section{Traverses Through the Phoenix Urban Plume}

[40] A Lagrangian determination of OPE requires measurements in the same air parcel upwind and downwind of an emission source, which in practice is difficult to obtain.

[41] Ozone production efficiencies are most commonly determined using measurements of $\mathrm{O}_{\mathrm{x}}$ and $\mathrm{NO}_{\mathrm{z}}$ from an aircraft traverse of a plume. Ideally, a plume transect would occur at a fixed downwind distance from a source so that there is a well defined atmospheric residence time. In practice, however, a plume traverse often samples air masses with different histories.

[42] Ozone production efficiencies have been determined as the slope of a linear least squares regression of $\mathrm{O}_{\mathrm{x}}$ versus $\mathrm{NO}_{z}$ for 20 plumes observed during the Phoenix field campaign. Figure 7 is an example from the afternoon flight on June 1, where the plume was observed less than $20 \mathrm{~km}$ from central downtown. These measurements are of particular interest because of the high correlation between $\mathrm{O}_{\mathrm{x}}$ and $\mathrm{NO}_{z}$ and because $\mathrm{O}_{3}$ concentration was close to the maximum seen during the field program. Because the plume is still over the Phoenix emission source region and since its width is comparable to the distance from the center of the city, it is likely that the air that is sampled has a mixture of atmospheric residence times and histories. Therefore OPE calculated in Figure 7, is not from a simple traverse of a plume at a fixed downwind distance, but corresponds instead to a more complicated sampling strategy. With this caveat in mind, we use Figure 7 to illustrate the difference between Lagrangian and Eulerian values of OPE as first discussed by Sillman [2000]. We have added a point to Figure 7, which is a hypothetical starting point for the June 1 urban plume. Two arrows are drawn connecting the hypothetical initial condition point to the low and high $\mathrm{NO}_{z}$ portions of the observed plume. The slope of each line is a Lagrangian value of OPE. A high OPE (17) occurs at low $\mathrm{NO}_{\mathrm{z}}$ representing efficient $\mathrm{O}_{3}$ production in the low $\mathrm{NO}_{\mathrm{x}}$ edge of the urban plume. A lower Lagrangian OPE 


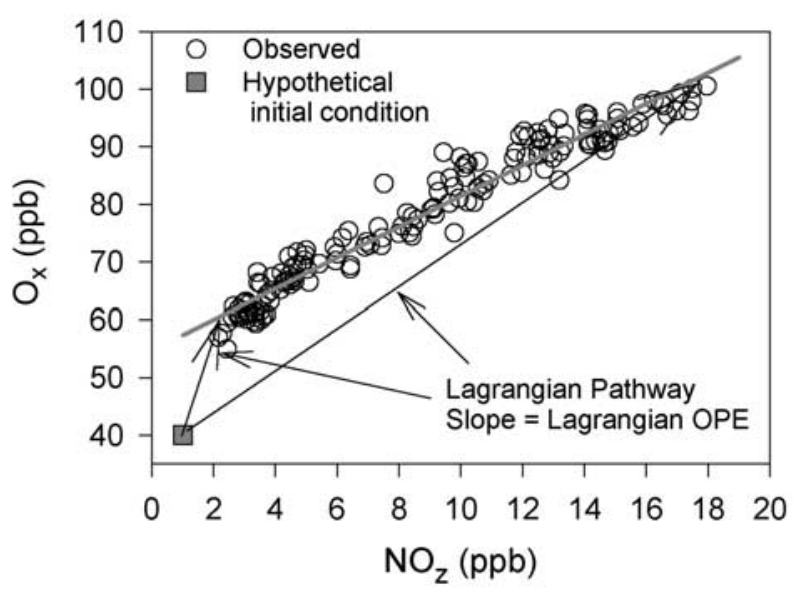

Figure 7. Correlation between $\mathrm{O}_{\mathrm{x}}$ and $\mathrm{NO}_{z}$ in a plume observed near downtown Phoenix on the afternoon of June 1 at $\approx 1000 \mathrm{~m}$ altitude from the G-1 aircraft. Each data point is a 10 -s average. Line through data points is a linear least squares fit. Ozone production efficiency from slope is 2.7 with $\mathrm{r}^{2}=0.95$. A hypothetical pathway to forming the plume is schematically indicated. The starting point is background air with $\mathrm{O}_{\mathrm{x}}=40 \mathrm{ppb}$ and $\mathrm{NO}_{\mathrm{z}}=1 \mathrm{ppb}$. The low concentration end of the observed plume evolves from this initial condition with minimal addition of emitted pollutants. The same initial conditions with a large addition of emitted pollutants gives rise to the high concentration end of the observed plume.

(3.7) applies to the plume center. Efficient $\mathrm{O}_{3}$ production at the plume edge causes, both Lagrangian OPE's to be greater than the observed "Eulerian" OPE (2.7).

[43] In Figure 8, we plot OPE as a function of the maximum $\mathrm{NO}_{\mathrm{x}}$ concentration observed in the plume. There is a trend, similar to that shown for instantaneous efficiency in Figures 3 and 6, whereby ozone production efficiency increases as $\mathrm{NO}_{\mathrm{x}}$ concentration is decreased. We note that using peak $\mathrm{NO}_{\mathrm{x}}$ concentration as a metric for ordering OPE is somewhat arbitrary as there is no guarantee that it reflects the conditions under which $\mathrm{O}_{3}$ was formed. Nevertheless, the most straightforward interpretation of Figure 8 is that the increase in OPE at low $\mathrm{NO}_{\mathrm{x}}$ is largely due to the increased instantaneous efficiency of $\mathrm{O}_{3}$ production at low $\mathrm{NO}_{\mathrm{x}}$.

\section{Conclusions}

[44] Observations taken during a field campaign in Phoenix, Arizona have been used as inputs to a constrained steady state box model which yields predictions for the rates of $\mathrm{O}_{3}$ production, $\mathrm{NO}_{x}$ oxidation and hence an instantaneous $\mathrm{O}_{3}$ production efficiency, $\mathrm{P}\left(\mathrm{O}_{3}\right) / \mathrm{P}\left(\mathrm{NO}_{\mathrm{z}}\right)$. A time dependent calculation yields the time evolution of $\mathrm{P}\left(\mathrm{O}_{3}\right) /$ $\mathrm{P}\left(\mathrm{NO}_{\mathrm{z}}\right)$. Ozone production efficiencies have been determined for the Phoenix urban plume as the slope of a regression of observed $\mathrm{O}_{\mathrm{x}}$ and $\mathrm{NO}_{\mathrm{z}}$.

[45] We find that:

1. Instantaneous values of $\mathrm{P}\left(\mathrm{O}_{3}\right) / \mathrm{P}\left(\mathrm{NO}_{\mathrm{z}}\right)$ are wellapproximated by a VOC to $\mathrm{NO}_{2}-\mathrm{OH}$ reactivity ratio (4) as long as the $\mathrm{NO}_{\mathrm{x}}$ concentration is above 1-2 ppb.
2. Time dependent calculations show that oxidation reactions and dilution with background air usually lead to an increase in $\mathrm{VOC}$ to $\mathrm{NO}_{2}-\mathrm{OH}$ reactivity ratio and hence an increase in $\mathrm{P}\left(\mathrm{O}_{3}\right) / \mathrm{P}\left(\mathrm{NO}_{\mathrm{z}}\right)$. An exception occurs near an emission source of reactive VOCs where $\mathrm{P}\left(\mathrm{O}_{3}\right) / \mathrm{P}\left(\mathrm{NO}_{\mathrm{z}}\right)$ decreases slightly until the most reactive VOCs are oxidized.

3. The time dependent variation of $\mathrm{P}\left(\mathrm{O}_{3}\right) / \mathrm{P}\left(\mathrm{NO}_{\mathrm{z}}\right)$ in a single air masses qualitatively reproduces the instantaneous $\mathrm{O}_{3}$ production efficiency versus $\mathrm{NO}_{\mathrm{x}}$ relation deduced from an ensemble of measurements taken in a diverse range of conditions. This feature is attributed to the circumstance that there is relatively little variation in the composition of emission sources in the Phoenix metropolitan area.

4. The integrated value of $\Delta \mathrm{O}_{\mathrm{x}} / \Delta \mathrm{NO}_{\mathrm{z}}$ is 1 less than the instantaneous value of $\mathrm{P}\left(\mathrm{O}_{3}\right) / \mathrm{P}\left(\mathrm{NO}_{z}\right)$, i.e., if $\mathrm{P}\left(\mathrm{O}_{3}\right) / \mathrm{P}_{\left(\mathrm{NO}_{\mathrm{z}}\right)}$ is a constant, $\mathrm{n}$, then $\Delta \mathrm{O}_{\mathrm{x}} / \Delta \mathrm{NO}_{\mathrm{z}}=\mathrm{n}-1$.

5. There is a simple scaling relation such that, for example, a doubling of $\left(\mathrm{P}\left(\mathrm{O}_{3}\right)-\mathrm{L}\left(\mathrm{O}_{3}\right)\right) / \mathrm{P}\left(\mathrm{NO}_{z}\right)$ results in a $2 \mathrm{n}+1$ change in $\Delta \mathrm{O}_{\mathrm{x}} / \Delta \mathrm{NO}_{\mathrm{z}}$. This relation, taken together with equation (4), which expresses $\mathrm{P}\left(\mathrm{O}_{3}\right) / \mathrm{P}\left(\mathrm{NO}_{\mathrm{z}}\right)$ by a VOC to $\mathrm{NO}_{2}-\mathrm{OH}$ reactivity ratio, serves as a basis for understanding city to city differences in OPE in terms of differences in a VOC to $\mathrm{NO}_{2}-\mathrm{OH}$ reactivity ratio.

6. In a set of traverses through the Phoenix urban plume, OPE increases as the $\mathrm{NO}_{\mathrm{x}}$ concentration at plume center decreases. This relation resembles the $\left(\mathrm{P}\left(\mathrm{O}_{3}\right)-\mathrm{L}\left(\mathrm{O}_{3}\right)\right) /$ $\mathrm{P}\left(\mathrm{NO}_{\mathrm{z}}\right)$ vs. $\mathrm{NO}_{\mathrm{x}}$ relation found in the ensemble of CSS calculations. However, there are atmospheric processes such as mixing and downwind emissions that affect $\Delta \mathrm{O}_{\mathrm{x}} / \Delta \mathrm{NO}_{\mathrm{z}}$ which have no counterpart in the instantaneous CSS calculations.

[46] To proceed further with the link between instantaneous efficiency (about which we have a good understanding) and $\Delta \mathrm{O}_{\mathrm{x}} / \Delta \mathrm{NO}_{\mathrm{z}}$, will require a side by side analysis of instantaneous chemistry and time integrated chemistry such

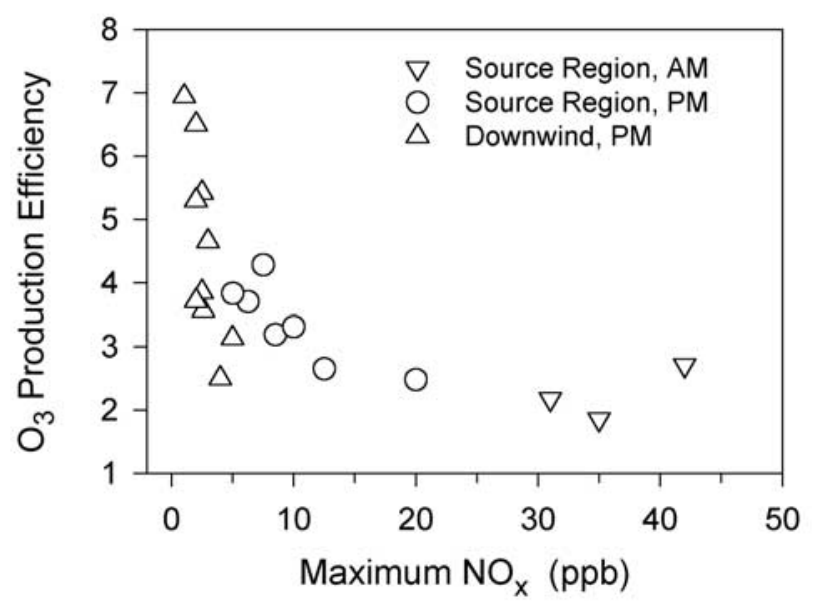

Figure 8. Ozone production efficiency determined as the slope of an $\mathrm{O}_{\mathrm{x}}$ versus $\mathrm{NO}_{z}$ graph (i.e., from plots similar to Figure 7) for 20 plumes, plotted as a function of the maximum $\mathrm{NO}_{\mathrm{x}}$ concentration in the plume. Location and time of plume are identified. 
as produced in an Eulerian model simulation. Among the questions to be addressed are: What are the effects of mixing and downwind emissions? How is OPE affected by a sampling strategy that combines air parcels with different ages and origins into a single graph of $\mathrm{O}_{\mathrm{x}}$ versus $\mathrm{NO}_{z}$ ? Why is there usually a high degree of correlation between $\mathrm{O}_{\mathrm{x}}$ and $\mathrm{NO}_{\mathrm{z}}$ despite a highly nonlinear relation between $\mathrm{P}\left(\mathrm{O}_{3}\right)$ and $\mathrm{P}\left(\mathrm{NO}_{\mathrm{z}}\right)$ ?

[47] Acknowledgments. We thank the pilots and flight crew from PNNL for a job well done. We gratefully acknowledge the Atmospheric Chemistry Program within the Office of Biological and Environmental Research of DOE for supporting the Phoenix field and analysis activities and for providing the G-1 aircraft. Support of field measurement activities by the Arizona Department of Environmental Quality is appreciated. JW-L acknowledges DOE support under grant DE-FG02-98ER62586. This research was performed under sponsorship of the U.S. DOE under contracts DE-AC02-98CH10886.

\section{References}

Atkinson, R., Atmospheric chemistry of VOCs and $\mathrm{NO}_{\mathrm{x}}$, Atmos. Environ., 34, 2063-2101, 2000.

Atkinson, R., D. L. Baulch, R. A. Cox, R. F. Hampson Jr., J. A. Kerr, M. J. Rossi, and J. Troe, Evaluated kinetic and photochemical data for atmospheric chemistry: Supplement VI, J. Phys. Chem. Ref. Data., 26, 13291499, 1997.

Carpenter, L. J., T. J. Green, G. P. Mills, S. Bauguitte, S. A. Penkett, P. Zanis, E. Schuepbach, N. Schmidbauer, P. S. Monks, and C. Zellweger, Oxidized nitrogen and ozone production efficiencies in the springtime free troposphere over the Alps, J. Geophys. Res., 105, 14,547-14,559, 2000.

Cleveland, W. S., and S. J. Devlin, Locally weighted regression: An approach to regression analysis by local fitting, J. Am. Stat. Assoc., 83, $596-610,1988$.

Daum, P. H., et al., Analysis of $\mathrm{O}_{3}$ formation during a stagnation episode in Central TN in summer 1995, J. Geophys. Res., 105, 9107-9120, 2000

Dentener, F. J., and P. J. Crutzen, Reaction of $\mathrm{N}_{2} \mathrm{O}_{5}$ on tropospheric aerosols: Impact on the global distributions of $\mathrm{NO}_{\mathrm{x}}, \mathrm{O}_{3}$, and $\mathrm{OH}, J$. Geophys Res., 98, 7149-7163, 1993.

Derwent, R. G., and T. J. Davies, Modelling the impact of $\mathrm{NO}_{\mathrm{x}}$ or hydrocarbon control on photochemical ozone in Europe, Atmos. Environ., 28 , 2039-2052, 1994.

Ehhalt, D. H., Photooxidation of trace gases in the troposphere: Plenary lecture, Phys. Chem. Chem. Phys., 1, 5401-5408, 1999.

Fast, J. D., J. C. Doran, W. J. Shaw, R. L. Coulter, and T. J. Martin, The evolution of the boundary layer and its effect on air chemistry in the Phoenix area, J. Geophys. Res., 105, 22,833-22,848, 2000.

Finlayson-Pitts, B. J., and J. N. Pitts Jr., Chemistry of the Upper and Lower Atmosphere: Theory, Experiments, and Applications, Academic, San Diego, Calif., 2000.

Gaffney, J. S., N. A. Marley, P. J. Drayton, M. M. Cunningham, J. C. Baird, J. Dintaman, and H. Hart, Phoenix, Arizona revisited: Indications of aerosol effects on $\mathrm{O}_{3}, \mathrm{NO}_{2}, \mathrm{UV}-\mathrm{B}$, and $\mathrm{NO}_{3}$, paper presented at Symposium on Atmospheric Chemistry: Issues in the 21st Century, Am. Meteorol. Soc., Long Beach, Calif., 9-14 January 2000.

Gillani, N. V., J. F. Meagher, R. J. Valente, R. E. Imhoff, R. L. Tanner, and M. Luria, Relative production of ozone and nitrates in urban and rural power plant plume, 1, Composite results based on data from 10 field measurement days, J. Geophys. Res., 103, 22,593-22,615, 1998.

Heisler, S. L., P. Hyde, M. Hubble, F. Keene, G. Neuroth, M. Ringsmuth, and W. R. Oliver, Reanalysis of the metropolitan Phoenix early ozone plan (VEOP), ENSR Doc. 0493-014-710, ENSR Consulting and Eng., Camarillo, Calif., October 1997.

Jacob, D. J., J. A. Logan, G. M. Gardner, R. M. Yevich, C. M. Spivakovsky, and S. C. Wofsy, Factors regulating ozone over the United States and its export to the global atmosphere, J. Geophys. Res., 98, 14,817-14,826, 1993.

Kasibhatla, P., W. L. Chameides, R. D. Saylor, and D. Olerud, Relationships between regional ozone pollution and emissions of nitrogen oxides in the eastern United States, J. Geophys. Res., 103, 22,663-22,669, 1998 .

Kleinman, L. I., Ozone process insights from field experiments, II, Observation-based analysis for ozone production, Atmos. Environ., 34, $2023-$ 2033, 2000
Kleinman, L. I., et al., Ozone formation at a rural site in the southeastern United States, J. Geophys. Res., 99, 3469-3482, 1994.

Kleinman, L. I., P. H. Daum, J. H. Lee, Y.-N. Lee, L. J. Nunnermacker, S. R. Springston, L. Newman, J. Weinstein-Lloyd, and S. Sillman, Dependence of ozone production on NO and hydrocarbons in the troposphere, Geophys. Res. Lett., 24, 2299-2302, 1997.

Kleinman, L. I., P. H. Daum, D. G. Imre, J. H. Lee, Y.-N. Lee, L. J. Nunnermacker, S. R. Springston, J. Weinstein-Lloyd, and L. Newman, Ozone production in the New York City Urban Plume, J. Geophys. Res., $105,14,495-14,511,2000$.

Kleinman, L. I., P. H. Daum, F. Brechtel, Y.-N. Lee, L. J. Nunnermacker, S. R. Springston, and J. Weinstein-Lloyd, Efficiency of ozone production in the Houston Plume, paper presented at Fourth Conference on Atmospheric Chemistry: Urban, Regional, and Global-Scale Impacts of Air Pollutants, Am. Meteorol. Soc., Orlando, Fla,, 13-17 January 2002.

Lee, Y.-N., et al., Atmospheric chemistry and distribution of formaldehyde and several multioxygenated compounds during the 1995 Nashville/Middle Tennessee Ozone Study, J. Geophys. Res., 103, 22,449-22,462, 1998.

Lewis, A. C., N. Carslaw, P. J. Marriott, R. M. Kinghorn, P. Morrison, A. L. Lee, K. D. Bartle, and M. J. Pilling, A larger pool of ozoneforming carbon compounds in urban atmospheres, Nature, 405, $778-$ 781, 2000.

Lin, X., M. Trainer, and S. C. Liu, On the nonlinearity of the tropospheric ozone production, J. Geophys. Res., 93, 15,879-15,888, 1988.

Liu, S. C., M. Trainer, F. C. Fehsenfeld, D. D. Parrish, E. J. Williams, D. W. Fahey, G. Hübler, and P. C. Murphy, Ozone production in the rural troposphere and the implications for regional and global ozone distributions, J. Geophys. Res., 92, 4191-4207, 1987.

Liu, S. C., et al., A study of the photochemistry and ozone budget during the Mauna Loa Observatory Photochemistry Experiment, J. Geophys. Res., 97, 10,463-10,471, 1992.

Luria, M., R. L. Tanner, R. E. Imhoff, R. J. Valente, E. M. Bailey, and S. F. Mueller, Influence of natural hydrocarbons on ozone formation in an isolated power plant plume, J. Geophys. Res., 105, 9177-9188, 2000.

Madronich, S., Photodissociation in the atmosphere, 1, Actinic flux and the effects of ground reflections and clouds, J. Geophys. Res., 92, 97409752, 1987.

Munger, J. W., S.-M. Fan, P. S. Bawkin, M. L. Goulden, A. H. Goldstein, A. S. Colman, and S. C. Wofsy, Regional budgets for nitrogen oxides from continental sources: Variations of rates for oxidation and deposition with season and distance from source regions, J. Geophys. Res., 103, 8355-8368, 1998.

Nunnermacker, L. J., et al., Characterization of the Nashville urban plume on July 3 and July 18, 1995, J. Geophys. Res., 103, 28,129-28,148, 1998.

Nunnermacker, L. J., L. I. Kleinman, D. Imre, P. H. Daum, Y.-N. Lee, J. H. Lee, S. R. Springston, L. Newman, and N. Gillani, $\mathrm{NO}_{\mathrm{y}}$ lifetimes and $\mathrm{O}_{3}$ production efficiencies in urban and power plant plumes: Analysis of field data, J. Geophys. Res., 105, 9165-9176, 2000.

Olszyna, K. J., E. M. Bailey, R. Simonaitis, and J. F. Meagher, $\mathrm{O}_{3}$ and $\mathrm{NO}_{\mathrm{y}}$ relationships at a rural site, J. Geophys. Res., 99, 14,557-14,563, 1994.

Paulson, S. E., and J. H. Seinfeld, Development and evaluation of a photochemical mechanism for isoprene, J. Geophys. Res., 97, 20,703-20,715, 1992.

Rudolph, J., Measurement of nonmethane hydrocarbons in the atmosphere, in Volatile Organic Compounds in the Troposphere, edited by R. Koppmann and D. H. Ehhalt, Proceedings of the Workshop on Volatile Organic Compounds in the Troposphere, Juelich (Germany) October 27-31, 1997, Schriftenr. Forsch. Jülich, 16, 11-35, 1999.

Ryerson, T. B., et al., Observations of ozone formation in power plant plumes and implications for ozone control strategies, Science, 292, 719-723, 2001.

Seinfeld, J. H., and S. N. Pandis, Atmospheric Chemistry and Physics: From Air Pollution to Climate Change, Wiley-Intersci., New York, 1997.

Sillman, S., The use of $\mathrm{NO}_{y}, \mathrm{HCHO}, \mathrm{H}_{2} \mathrm{O}_{2}$ and $\mathrm{HNO}_{3}$ as indicators for ozone- $\mathrm{NO}_{\mathrm{x}}$-hydrocarbon sensitivity in urban locations, J. Geophys. Res., $100,14,175-14,188,1995$

Sillman, S., Ozone production efficiency and loss of $\mathrm{NO}_{\mathrm{x}}$ in power plant plumes: Photochemical model and interpretation of measurements in Tennessee, J. Geophys. Res., 105, 9189-9202, 2000.

Sillman, S., J. A. Logan, and S. C. Wofsy, The sensitivity of ozone to nitrogen oxides and hydrocarbons in regional ozone episodes, J. Geophys. Res., 95, 1837-1851, 1990.

St. John, J. C., W. L. Chameides, and R. Saylor, Role of anthropogenic $\mathrm{NO}_{\mathrm{x}}$ and VOC as ozone precursors: A case study from SOS Nashville/Middle Tennessee Ozone Study, J. Geophys. Res., 103, 22,415-22,423, 1998. 
Stockwell, W. R., P. Middleton, J. S. Chang, and X. Tang, The second generation regional acid deposition model chemical mechanism for regional air quality modeling, J. Geophys. Res., 95, 16,343-16,367, 1990.

Tonnesen, G. S., and R. L. Dennis, Analysis of radical propagation efficiency to assess ozone sensitivity to hydrocarbons and $\mathrm{NO}_{\mathrm{x}}, 1$, Local indicators of instantaneous odd oxygen production sensitivity, J. Geophys. Res., 105, 9213-9225, 2000.

Trainer, M., et al., Correlation of ozone with $\mathrm{NO}_{\mathrm{y}}$ in photochemically aged air, J. Geophys. Res., 98, 2917-2925, 1993.

Weinstein-Lloyd, J. B., J. H. Lee, P. H. Daum, L. I. Kleinman, L. J. Nunnermacker, S. R. Springston, and L. Newman, Measurements of peroxides and related species during the 1995 summer intensive of the
Southern Oxidants Study in Nashville, Tennessee, J. Geophys. Res., 103, 22,361-22,373, 1998.

P. H. Daum, L. I. Kleinman, Y.-N. Lee, L. J. Nunnermacker, and S. R. Springston, Atmospheric Sciences Division, Brookhaven National Laboratory, Upton, NY 22973, USA. (phdaum@bnl.gov; kleinman@bnl.gov; ynlee@bnl.gov; lindan@bnl.gov; srs@bnl.gov)

J. Rudolph, Chemistry Department and Centre for Atmospheric Research, York University, Toronto, Ont. M3J IP3, Canada. (rudolphj@yorku.ca)

J. Weinstein-Lloyd, Chemistry/Physics Department, State University of New York, at Old Westbury, Old Westbury, NY 11568, USA. (jlloyd@ bnl.gov) 